\title{
The Radiation Chemistry of Gaseous Ammonia
}

\section{Donald B. Peterson}

University of San Diego

San Diego, California 92110

Prepared at the

Radiation Chemistry Data Center,

Radiation Laboratory,

University of Notre Dame,

Notre Dame, Ind. 46556

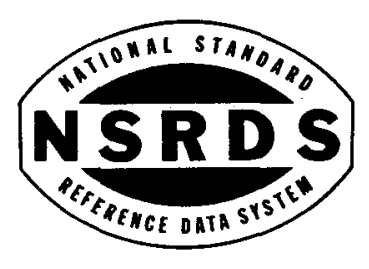

This report was prepared as an account of work sponsored by the United States Government. Neither the United States nor the United States Department of Energy, nor any of their employees, nor any of their contractors, subcontractors, or their employees, makes any warranty, express or implied, or assumes any legal liability or responsibility for the accuracy, completeness or usefulness of any information, apparatus, product or process disclosed, or represents that its use would not infringe privately owned rights.

U.S. DEPARTMENT OF COMMERCE, Frederick B. Dent, Secretary NATIONAL BUREAU OF STANDARDS, Richard W. Roberts, Director

Issued February 1974 


\section{DISCLAIMER}

This report was prepared as an account of work sponsored by an agency of the United States Government. Neither the United States Government nor any agency Thereof, nor any of their employees, makes any warranty, express or implied, or assumes any legal liability or responsibility for the accuracy, completeness, or usefulness of any information, apparatus, product, or process disclosed, or represents that its use would not infringe privately owned rights. Reference herein to any specific commercial product, process, or service by trade name, trademark, manufacturer, or otherwise does not necessarily constitute or imply its endorsement, recommendation, or favoring by the United States Government or any agency thereof. The views and opinions of authors expressed herein do not necessarily state or reflect those of the United States Government or any agency thereof. 


\section{DISCLAIMER}

Portions of this document may be illegible in electronic image products. Images are produced from the best available original document. 


\section{Library of Congress Catalog Number: 72-600106}

\section{NSRDS-NBS 44}

Nat. Stand. Ref. Data Ser., Nat. Bur. Stand. (U.S.), 44, 40 pages (Feb. 1974) CODEN: NSRDAP

(C) 1974 by the Secretary of Commerce on Behalf of the United States Government
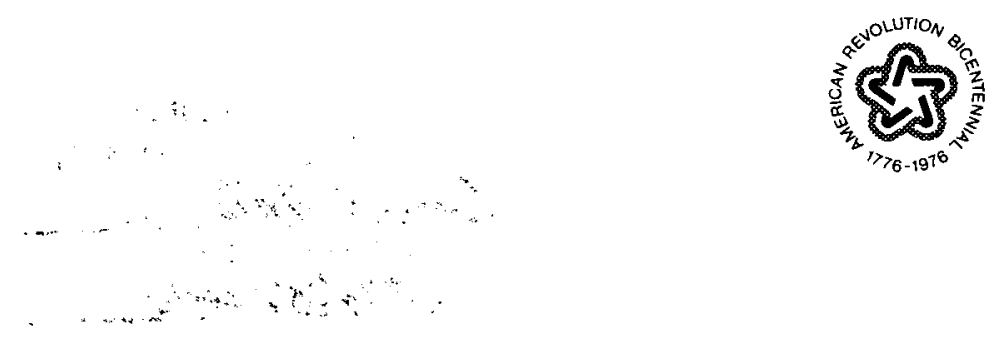

U.S. GOVERNMENT PRINTING OFFICE WASHINGTON: 1974

For sale by the Superintendent of Documents. U.S. Government Printing Office, Washington, D.C. 20402 (Order by SD Catalog No. C13.48:44). Price 70 cents Stock Number 0303-01164 


\section{Foreword}

The National Standard Reference Data System provides access to the quantitative data of physical science, critically evaluated and compiled for convenience and readily accessible through a variety of distribution channels. The System was established in 1963 by action of the President's Office of Science and Technology and the Federal Council for Science and Technology, and responsibility to administer it was assigned to the National Bureau of Standards.

NSRDS receives advice and planning assistance from a Review Committee of the National Research Council of the National Academy of Sciences-National Academy of Engineering. A number of Advisory Panels, each concerned with a single technical area, meet regularly to examine major portions of the program, assign relative priorities, and identify specific key problems in need of further attention. For selected specific topics, the Advisory Panels sponsor subpanels which make detailed studies of users' needs, the present state of knowledge, and existing data resources as a basis for recommending one or more data compilation activities. This assembly of advisory services contributes greatly to the guidance of NSRDS activities.

The System now includes a complex of data centers and other activities in academic institutions and other laboratories. Components of the NSRDS produce compilations of critically evaluated data, reviews of the state of quantitative knowledge in specialized areas, and computations of useful functions derived from standard reference data. The centers and projects also establish criteria for evaluation and compilation of data and recommend improvements in experimental techniques. They are normally associated with research in the relevant field.

The technical scope of NSRDS is indicated by the categories of projects active or being planned: nuclear properties, atomic and molecular properties, solid state properties, thermodynamic and transport properties, chemical kinetics, and colloid and surface properties.

Reliable data on the properties of matter and materials is a major foundation of scientific and technical progress. Such important activities as basic scientific research, industrial quality control, development of new materials for building and other technologies, measuring and correcting environmental pollution depend on quality reference data. In NSRDS, the Bureau's responsibility to support American science, industry, and commerce is vitally fulfilled.

RICHARD W. RoBerTs, Director 


\section{Preface}

This report is one of a series of data publications on radiation chemistry; the aim of the series is to compile, evaluate, and present the numerical results on processes occurring in systems which have been subjected to ionizing radiation. Various kinds of data are important in radiation chemistry. The quantities which were measured first were the observed radiation yields or $G$ values (molecules formed or destroyed per $100 \mathrm{eV}$ ). Various indirect methods based on $G$ values have been used to determine yields of transient species and relative rates of reactions. The spectral properties (optical, electron spin resonance) of transients have provided a direct method for their identification, and rates of the very fast reactions of transients which occur in irradiated systems have been measured directly by spectroscopic methods. Conductivity and luminescence methods have also provided a means of measuring properties of transients and their kinetics. Some reactions which occur in irradiated systems have also been studied by other methods, such as photochemistry, electric discharge, ultrasonics, chemical initiation, electron impact, etc. The emphasis in these publications is on the data of radiation chemistry, but where other pertinent data exist, they are included.

The data of radiation chemistry are voluminoús; thousands of systems have been investigated. As a result there are certain collections, e.g. rate constants of particular types of reactions or certain properties of transients, for which tabulations of the data are considered essential, but for which critical assessment of each value is impossible. On the other hand, certain systems and properties have been studied so extensively that critical examination of these data is desirable and timely. Authors of this series of data publications have been asked to evaluate the extent to which the data can be critically assessed, to describe their criteria for evaluation, and to designate preferred values whenever possible. 


\section{Contents}

Foreword

Preface

1. Introduction

2. Mechanism

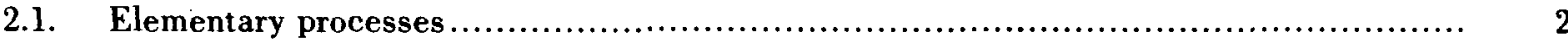

2.1.1. Elementary processes involving ions and excited neutrals .....................

2.1.2. Free radical processes....................................................... 5

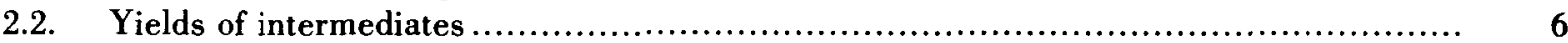

2.2.1. Neutral species..............................................................

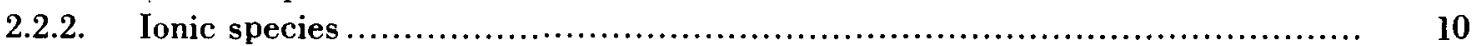

3. Product yields ........................................................................... 10

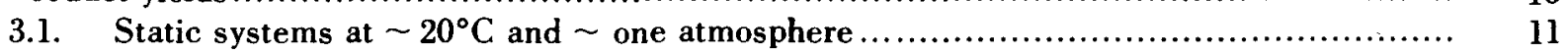

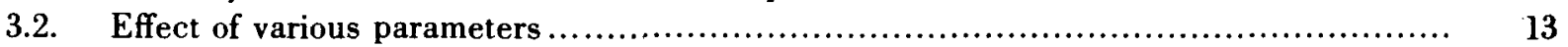

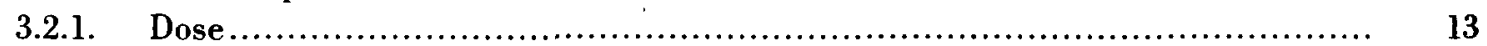

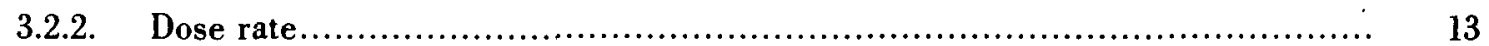

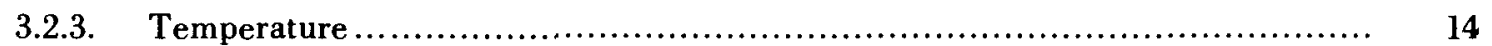

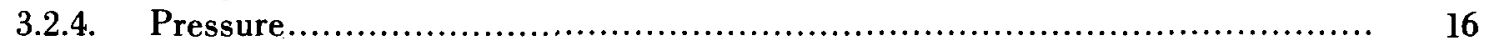

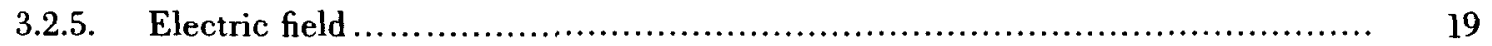

3.2.6. Flow rate.............................................................. 19

Appendix 1. Selected properties of species involved in radiolysis of gaseous ammonia............ 20

Appendix 2. Additives used in studies of ammonia radiolysis ..................................... 22

References

\section{List of Tables}

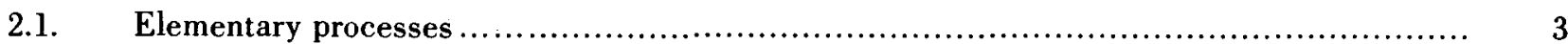

2.1.1. Yield of intermediates in radiolysis of gaseous ammonia ......................................

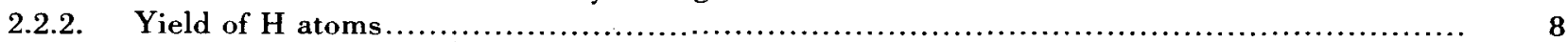

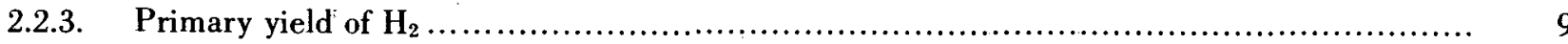

3.1.1. Product yields from radiolysis of gaseous ammonia with various radiations under static conditions at $\sim 20^{\circ} \mathrm{C}$ and $\sim 1$ atm.

.

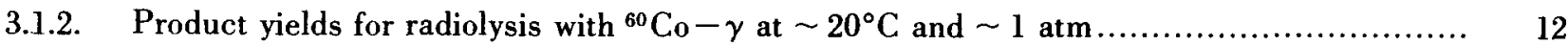

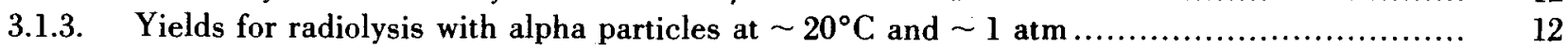

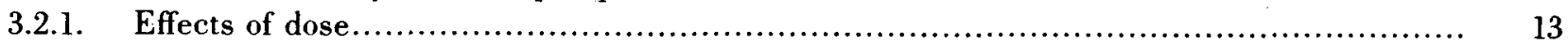

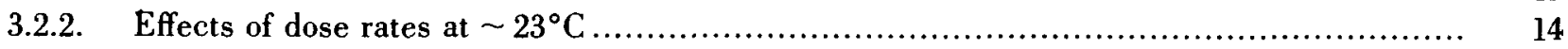

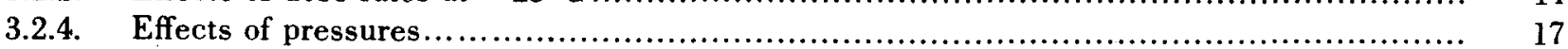

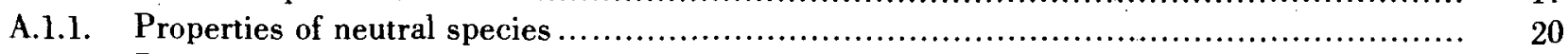

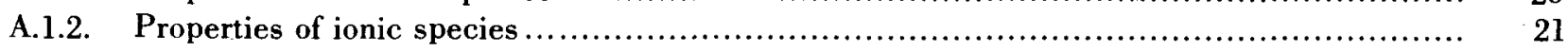

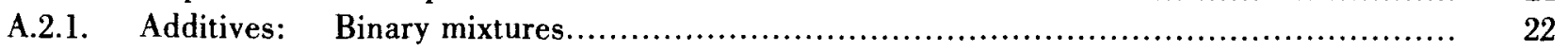

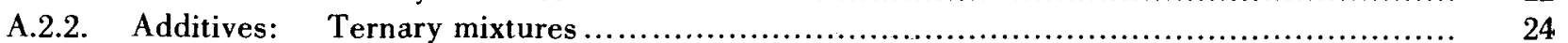

\section{List of Figures}

3.2.3.1. Variation of $G\left(-\mathrm{NH}_{3}\right)$ with temperature at dose rates less than $10^{19} \mathrm{eV} \cdot \mathrm{g}^{-1} \mathrm{~s}^{-1} \ldots \ldots \ldots \ldots \ldots$

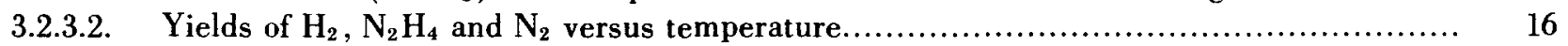

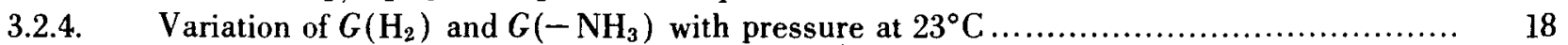




\title{
The Radiation Chemistry of Gaseous Ammonia*
}

\author{
Donald B. Peterson
}

\author{
University of San Diego, San Diego, California 92110
}

\begin{abstract}
$\mathrm{H}_{2}$ and $\mathrm{N}_{2}$ are the only significant products of radiolysis of gaseous ammonia under static conditions at dose rates less than about $10^{19} \mathrm{eV}^{\mathrm{n}} \cdot \mathrm{g}^{-1} \mathrm{~s}^{-1} ;$ and $G\left(\mathrm{H}_{2}\right)=5.0 \pm 1.0$ and $G\left(\mathrm{~N}_{2}\right)=1.7 \pm 0.3$ for irradiation at $20^{\circ} \mathrm{C}$ and pressures near one atmosphere. Yiclds do not appear to depend significantly upon LET (linear energy transfer); and they are independent of dose up to at least $8 \times 10^{22} \mathrm{eV} / \mathrm{g}$. In static systems at dose rates $\geqslant 10^{26} \mathrm{eV} \cdot \mathrm{g}^{-1} \mathrm{~s}^{-1}$, and in flow systems, $\mathrm{N}_{2} \mathrm{H}_{4}$ is also a product.

At dose rates less than $10^{19} \mathrm{eV} \cdot \mathrm{g}^{-1} \mathrm{~s}^{-1}, G\left(-\mathrm{NH}_{3}\right)$ increases markedly with temperature and reaches a plateau value of about 10 at temperatures near $150-200^{\circ} \mathrm{C}$. At very high dose rates $\left(\geqslant 10^{26} \mathrm{eV} \cdot \mathrm{g}^{-1} \mathrm{~s}^{-3}\right)$ $G\left(-\mathrm{NH}_{3}\right)$ increases significantly at higher temperatures (value depends upon dose rate) and $G\left(-\mathrm{NH}_{3}\right)$ does not appear to be leveling off at the highest temperature studied $\left(460^{\circ} \mathrm{C}\right)$. In both dose rate regions the increase in $\mathrm{G}\left(-\mathrm{NH}_{3}\right)$ is attributed primarily to the increasing importance of $\mathrm{NH}_{3}+\mathrm{H} \rightarrow$ $\mathrm{NH}_{2}+\mathrm{H}_{2}$ with increasing temperature. $G\left(-\mathrm{NH}_{3}\right)$ also appears to increase with decreasing dose rate. However, the effect is less pronounced than the effect of temperature, and the experimental evidence is not unequivocal.

$\mathrm{NH}$ and $\mathrm{NH}_{2}$ have been observed spectroscopically in pulse radiolysis of $\mathrm{NH}_{3}$ and such studies lead to $g(\mathrm{NH})=0.4$. However, this value of $g(\mathrm{NH})$ is low because of errors in dosimetry. $g\left(\mathrm{NH}_{2}\right)$ was not obtained directly because the absorptivity of $\mathrm{NH}_{2}$ was not available. A number of additives has been employed in attempts to determine primary yields of other species involved in radiolysis; however, results with different additives and from different laboratories are in good agreement only in the case of $g\left(\mathrm{H}_{2}\right)(0.7-0.8)$ and $g\left(\mathrm{NH}_{4}{ }^{+}\right)(3.3-3.9)$. The best value of $g(\mathrm{H})$ appears to be $10.4 \pm 0.6$; and this is the preferred value. $g\left(\mathrm{NH}_{2}\right)$ is obtained from the material balance, $g(\mathrm{H})+2 g\left(\mathrm{H}_{2}\right)=g\left(\mathrm{NH}_{2}\right)+2 g(\mathrm{NH})$. The preferred value of $g(\mathrm{NH})$ is 0.75 , i.e., $g(\mathrm{NH})=g\left(\mathrm{H}_{2}\right)$ and this leads to $g\left(\mathrm{NH}_{2}\right)=10.4$.
\end{abstract}

Key words: Ammonia; chemical kinetics; data compilation; $G ; g$; gas; radiation chemistry; rates; review.

\section{Introduction}

This compendium provides a comprehensive summary of data relevant to the radiation chemistry of gaseous ammonia A complete mechanism for the radiolysis of ammonia cannot be written at present. However, probable contributing processes are discussed in some detail and the supporting evidence is examined critically when possible. Specific rates and/or energies of activation for these elementary processes are given when available but in general such data are not critically evaluated. Properties such as bond energies, ionization energies and electron affinities are tabulated for the major intermediates (app. 1). Such data have for the most part been taken from authoritative reference sources and are presented without critical comment. Preferred values are given for yields of both products (sec.3) and intermediates (sec. 2.2.1 and 2.2.2).

Throughout the text and tables references are cited by Radiation Chemistry Data Center serial number; in many cases, the authors, or first author only, are included with serial number for easy identification of the work. When only a first author is cited, that name is followed by periods corresponding to the number of co-authors, as Nishikawa..68-0505. The bibliography is a listing of references by serial number; the first two digits of the number represent the year, so that the

*This is a data review prepared for, and in cooperation with, the Radiation Chemistry Data Center of the Radiation Laboratory, University of Notre Dame, Indiana 46556. The Laboratory is operated under contract with the Atomic Energy Commission. The work of the Center is supported in part by the National Bureau of Standards, Office of Standard Reference Data. 
listing is approximately chronological. The literature has been covered through the first half of 1970; however, a few selected papers published later are included.

\section{Symbols and Units}

Radiation yields are in units of molecules per $100 \mathrm{eV}$ and are designated $G(X)$ when $X$ is a reaction product. $G\left(-\mathrm{NH}_{3}\right)$ represents molecules of ammonia converted to reaction products per $100 \mathrm{eV}$ of energy absorbed. Various conventions have been used for reporting yields of intermediates. In this review such yields (in molecules per $100 \mathrm{eV}$ ) will be designated by use of the symbol $g$.

Other symbols used to designate properties, and the units in which values of the properties have been reported in this review, are listed below. A list of conversion factors is also included when non-SI (Système International) units have been used.

$D$, bond dissociation energy, $\mathrm{kcal} / \mathrm{mol}$.

$E_{\text {a }}$, activation energy, $\mathrm{kcal} / \mathrm{mol}$.

$E$. $A$., electron affinity, $\mathrm{eV}$.

$\Delta H_{\mathrm{f}}^{\circ}$, standard heat of formation, $\mathrm{kcal} / \mathrm{mol}$.

I.P., ionization potential, eV.

$k$, specific rate, second order processes in $\mathrm{dm}^{3} \mathrm{~mol}^{-1} \mathbf{s}^{-1}$.

$P$, pressure, atm or torr.

$P . A$., proton affinity, $\mathrm{eV}$.

$t$, temperature, ${ }^{\circ} \mathrm{C}$

$\Phi$, quantum yield.

\section{Conversion factors:}

$$
\begin{aligned}
& 1 \mathrm{kcal}=4.184 \mathrm{~kJ} \\
& 1 \mathrm{~atm}=101325 \mathrm{~N} / \mathrm{m}^{2} \\
& 1 \mathrm{torr}=133.32 \mathrm{~N} / \mathrm{m}^{2} \\
& 1 \mathrm{eV}=1.602 \times 10^{-19} \mathrm{~J}
\end{aligned}
$$

\section{Mechanism}

\subsection{Elementary Processes}

Because the relative importance of various elementary processes involved in radiolysis of gaseous ammonia depends upon such factors as dose rate, temperature and pressure, it is not possible to write a single mechanism which will be applicable under all conditions. The significant elementary processes that should be considered in mechanisms for radiolysis of gaseous ammonia are summarized in table 2.1.

Formation and reaction of $\mathrm{NH}_{4}$ are not included. There is some evidence for this species from mass spectrometric studies (67-9004) and its possible formation via $\mathrm{NH}_{3}+\mathrm{H}+\mathrm{M}$ in photochemical systems has been discussed (44-7000, 34-7002). Simic and Johnson (68-0659) have considered it as a possible intermediate in radiolysis of $\mathrm{NH}_{3}$. At this time, however, evidence is very limited.

\subsubsection{Elementary Processes Involving Ions and Exeited Neutrals}

There is considerable experimental evidence in support of the general assumption that ions and excited neutrals produced in reactions. (1) and (2) (table 2.1) lead principally to $\mathrm{NH}_{2}$ and $\mathrm{H}$; $\mathrm{NH}$ and $\mathrm{H}_{2}$ are also produced but in relatively small yields. (See table 2.2.1.) 


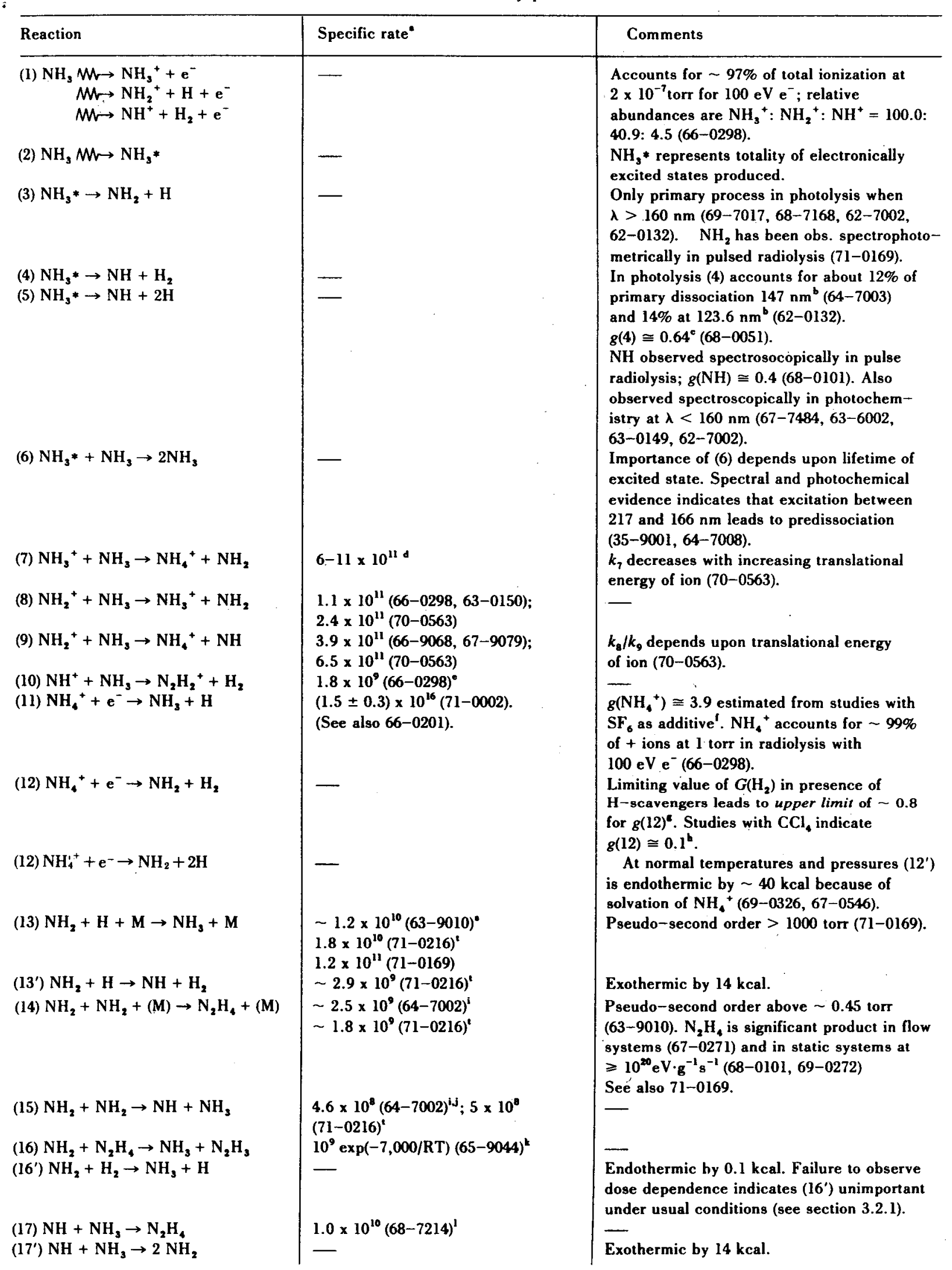


$\mathrm{T}_{\mathrm{ABLE}}$ 2.1. Elementary processes - Continued

\begin{tabular}{|c|c|c|}
\hline Reaction & Specific rate & Comments \\
\hline $\begin{array}{l}\text { (18) } \mathrm{NH}+\mathrm{NH} \rightarrow \mathrm{N}_{2} \mathrm{H}_{2} * \rightarrow \mathrm{N}_{2}+\mathrm{H}_{2} \\
\text { (19) } \mathrm{NH}+\mathrm{N}_{2} \mathrm{H}_{4} \rightarrow \mathrm{NH}_{2}+\mathrm{N}_{2} \mathrm{H}_{3} \\
\text { (20) } \mathrm{NH}+\mathrm{NH}_{2}+(\mathrm{M}) \rightarrow \mathrm{N}_{2} \mathrm{H}_{3}+(\mathrm{M}) \\
\text { (21) } \mathrm{NH}+\mathrm{H}+(\mathrm{M}) \rightarrow \mathrm{NH}_{2}+(\mathrm{M}) \\
\text { (22) } \mathrm{H}+\mathrm{N}_{2} \mathrm{H}_{4} \rightarrow \mathrm{H}_{2}+\mathrm{N}_{2} \mathrm{H}_{3} \\
(22) \mathrm{H}+\mathrm{N}_{2} \mathrm{H}_{4} \rightarrow \mathrm{NH}_{3}+\mathrm{NH}_{2} \\
\text { (23) } \mathrm{H}+\mathrm{NH}_{3} \rightarrow \mathrm{H}_{2}+\mathrm{NH}_{2} \\
\quad \\
\text { (24) } \mathrm{H}+\mathrm{H}+\mathrm{M} \rightarrow \mathrm{H}_{2}+\mathrm{M} \\
\text { (25) } \mathrm{N}_{2} \mathrm{H}_{3}+\mathrm{NH}_{2} \rightarrow \mathrm{N}_{2} \mathrm{H}_{2}+\mathrm{NH}_{3} \\
\text { (26) } \mathrm{N}_{2} \mathrm{H}_{3}+\mathrm{H} \rightarrow \mathrm{N}_{2} \mathrm{H}_{2}+\mathrm{H}_{2} \\
\text { (27) } \mathrm{N}_{2} \mathrm{H}_{3}+\mathrm{N}_{2} \mathrm{H}_{3} \rightarrow 2 \mathrm{NH}_{3}+\mathrm{N}_{2} \\
\text { (28) } \mathrm{N}_{2} \mathrm{H}_{3}+\mathrm{N}_{2} \mathrm{H}_{3} \rightarrow \mathrm{N}_{2} \mathrm{H}_{2}+\mathrm{N}_{2} \mathrm{H}_{4} \\
\text { (29) } \mathrm{N}_{2} \mathrm{H}_{2} \rightarrow \mathrm{N}_{2}+\mathrm{H}_{2} \\
\text { (30) } \mathrm{N}_{2} \mathrm{H}_{2}+\mathrm{N}_{2} \mathrm{H}_{2} \rightarrow \mathrm{N}_{2}+\mathrm{N}_{2} \mathrm{H}_{4}\end{array}$ & 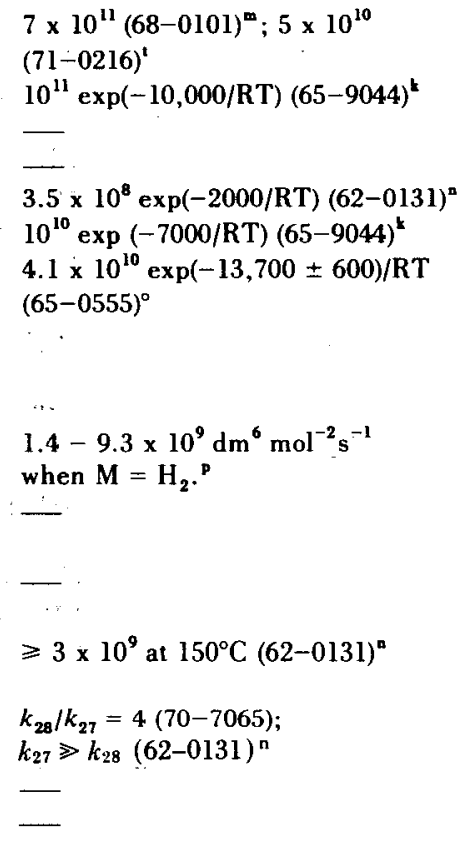 & 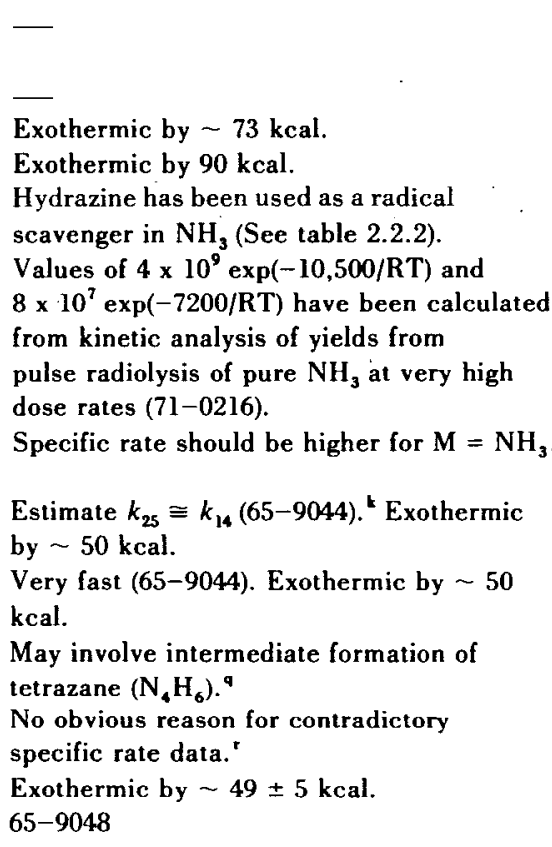 \\
\hline
\end{tabular}

a. Unless otherwise indicated specific rates are in units of $\mathrm{dm}^{3} \cdot \mathrm{mol}^{-1} \mathrm{~s}^{-1}$ and apply to temperatures near $25^{\circ} \mathrm{C}$.

b. Based on limiting $\Phi\left(\mathrm{H}_{2}\right)$ in presence of $\mathrm{C}_{2} \mathrm{D}_{4}$.

c. $\mathrm{CCl}_{4}$ reduces $G\left(\mathrm{H}_{2}\right)$ to $0.64 \mathrm{CCl}_{4}$ assumed to scavenge both $\mathrm{e}-$ and $\mathrm{H}$ and thus (4) is only significant source of $\mathrm{H}_{2}$ in $\mathrm{NH}_{3}-\mathrm{CCl}_{4}$. (See sec. 2.1.1.)

d. Values reported are $6.0(66-9068,67-9079), 7.8(66-0298), 9.0(63-0150)$ and $10.9(70-0563)$ in units of $10^{11}$ $\mathrm{dm}^{3} \cdot \mathrm{mol}^{-1} \mathrm{~s}^{-1}$.

e. See also $63-0150$.

f. See table 2.2.1.

g. See table 2.2.3.

h. Based on difference between $G\left(\mathrm{H}_{2}\right)$ for $\mathrm{NH}_{3}+\mathrm{CCl}_{4}$ (see $c$ above) and $G\left(\mathrm{H}_{2}\right)$ from $\mathrm{NH}_{3}+\mathrm{C}_{3} \mathrm{H}_{6}(68-0051)$.

i. Determined by following decay of $\mathrm{NH}_{2}$ absorption following r.f. discharge through $\mathrm{NH}_{3}$. Based on limited data and subject to uncertainties in absorptivity of $\mathrm{NH}_{2}$.

j. At $2000 \mathrm{~K}, k_{15} \cong 2.5 \times 10^{10} \mathrm{dm}^{3} \cdot \mathrm{mol}^{-1} \mathrm{~s}^{-1}(63-0167) ; k_{14} \cong k_{15}$ has also been reported from studies at room temperature (absolute rate data not reported) (67-9109).

k. From analysis of the overall energy of activation of decomposition of $\mathrm{N}_{2} \mathrm{H}_{4}$ on the basis of an assumed mechanism involving (16).

1. Determined by kinetic spectroscopy in flash photolysis of $\mathrm{NH}_{3}$.

$\mathrm{m}$. Upper limit. Based on kinetic spectroscopy in pulse radiolysis of $\mathrm{NH}_{2} ; k_{18} \cong 10^{\mathrm{Il}} \mathrm{dm}^{3} \cdot \mathrm{mol}^{-1} \mathrm{~s}^{-1}$ at $2000 \mathrm{~K}$ (63-0167).

n. $\mathrm{H}$ atoms from microwave discharge flowed into $\mathrm{N}_{2} \mathrm{H}_{4}$ vapor; reaction followed by mass spectrometry; temp. range $25^{\circ}$ to $150^{\circ} \mathrm{C}$.

o. Also, $k_{23} \cong 10^{4} \mathrm{dm}^{3} \cdot \mathrm{mol}^{-1} \mathrm{~s}^{-1}$ at $150^{\circ} \mathrm{C}$ and $E_{\text {. }} \cong 10-15 \mathrm{kcal} / \mathrm{mol}(62-0131)$.

p. Values reported are 1.35 (68-5013), 3.4 (64-0288), 5.0 (38-9001), 5.5 (35-0002), 8.5 (34-0005), 8.9 (63-9014), $9.3(61-9008)$ in units of $10^{9} \mathrm{dm}^{6} \cdot \mathrm{mol}^{-2} \mathrm{~s}^{-1}$. See also 65-9041, 67-9108 and 70-9010. Bennett and Blackmore (68-5013) give a critical comparison of specific rates of $\mathrm{H}+\mathrm{H}$ with $\mathrm{H}_{2}$ as third-body.

q. $\mathrm{N}_{4} \mathrm{H}_{6} \rightarrow \mathrm{NH}_{3}+\mathrm{NH}=\mathrm{N}-\mathrm{NH}_{2} ; \mathrm{HN}=\mathrm{N}-\mathrm{NH}_{2} \longleftrightarrow \mathrm{NH}_{2}-\mathrm{N}=\mathrm{NH} ; \mathrm{N}_{3} \mathrm{H}_{3} \rightarrow \mathrm{NH}_{3}+\mathrm{N}_{2}$ (70-7065, 54-9005).

r. Conclusion that $k_{27} \gg k_{28}$ is based on simple observation that $\mathrm{NH}_{3}$ and $\mathrm{N}_{2}$ in 2:1 ratio are only products when $\mathrm{H}$ atoms flow into $\mathrm{N}_{2} \mathrm{H}_{4}$ (see $n$ above). $k_{28} / k_{27}=4$ is based on a more complicated analysis of isotopic nitrogens from reaction of $\mathrm{H}$ atoms with isotopically labeled hydrazines.

s. Estimated from collision theory.

t. Value calculated by kinetic analysis of product yields from pulse radiolysis of $\mathrm{NH}_{3}$ on basis of an assumed mechanism. 
Photochemical studies indicate that $(3)$ is

$$
\text { (3) } \mathrm{NH}_{3} * \rightarrow \mathrm{NH}_{2}+\mathrm{H}
$$

the only dissociation process at wavelengths greater than $160 \mathrm{~nm}$ (ref. in table 2.1). At shorter wavelengths (4) and (5) also occur, however reactions (3) and (5) account for 80\% of the dissociation.

$$
\begin{aligned}
& \text { (4) } \mathrm{NH}_{3} * \rightarrow \mathrm{NH}+\mathrm{H}_{2} \\
& \text { (5) } \mathrm{NH}_{3} * \rightarrow \mathrm{NH}+2 \mathrm{H}
\end{aligned}
$$

The spectra of both $\mathrm{NH}_{2}(71-0169)$ and $\mathrm{NH}(68-0101)$ have been observed in pulsed radiolysis. Primary positive ions from (1) undergo rapid ion-molecule reactions (7) - (10) and are thereby converted almost exclusively to $\mathrm{NH}_{4}{ }^{+}(66-0298)$. The relative importance of possible modes of neutralization of $\mathrm{NH}_{4}^{+}(11),(12)$, and $\left(12^{\prime}\right)$ has been investigated by addition of electron scavengers. In pure ammonia, $\mathrm{NH}_{4}{ }^{+}$is neutralized by $\mathrm{e}^{-}$since negative ion formation is negligible (66-0298, 34-9002). In the presence of electron scavengers, $\mathrm{NH}_{4}^{+}$is neutralized by the negative ion formed in the scavenging process.

Nishikawa and co-workers $(67-0263,68-0051)$ have studied the system $\mathrm{NH}_{3}-\mathrm{CCl}_{4}$. They assume $\mathrm{CCl}_{4}$ scavenges electrons in a dissociative attachment that leads to $\mathrm{CCl}_{3}$ and $\mathrm{Cl}^{-}$, and that neutralization of $\mathrm{NH}_{4}^{+}$with $\mathrm{Cl}^{-}$yields $\mathrm{NH}_{4} \mathrm{Cl}$. Because $\mathrm{CCl}_{4}$ also scavenges $\mathrm{H}$ atoms, the limiting value of $G\left(\mathrm{H}_{2}\right)$ in the presence of $\mathrm{CCl}_{4}$ should be the primary yield of non-scavengable $\mathrm{H}_{2}$ from processes other than (12).

$$
\text { (12) } \mathrm{NH}_{4}^{+}+\mathrm{e}^{-} \rightarrow \mathrm{NH}_{2}+\mathrm{H}_{2}
$$

Comparison of this limiting yield of 0.64 with the total non-radical yield of 0.75 (see table 3.2 .1 ) leads to the conclusion that $g(12) \sim 0.1$.

Neutralization of $\mathrm{NH}_{4}^{+}$to give $\mathrm{NH}_{2}$ and $2 \mathrm{H}\left(12^{\prime}\right)$ is endothermic by about 40 kcal $(69-0326,67-$ 0546) if, as seems reasonable, $\mathrm{NH}_{4}{ }^{+}$is solvated at normal temperature and pressures (68-0032, 66-9067, 64-9015). Thus, it appears that neutralization of $\mathrm{NH}_{4}^{+}$in pure ammonia proceeds almost exclusively by reaction (11). In support of such a conclusion, Gordon, Mulac, and Nangia (71-0169) have found that the initial concentration of $\mathrm{NH}_{2}$ measured spectrophotometrically, is unchanged when $\mathrm{SF}_{6}$ is added to $\mathrm{NH}_{3}$.

Gordon, Mulac and Nangia (71-0169) also conclude from the comparison of results for pure $\mathrm{NH}_{3}$ and $\mathrm{NH}_{3}-\mathrm{SF}_{6}$ that 45 percent of the hydrogen atoms are produced by ion-neutralization as opposed to dissociation of excited states. This can be compared with the results of Nishikawa and co-workers $(67-0263,68-0051)$ who reported that approximately 42 percent of the hydrogen $\left(\mathrm{H}_{2}\right)$ is the result of ion-neutralization. The latter estimate is based upon a comparison of hydrogen yields from $\mathrm{NH}_{3}$ and $\mathrm{NH}_{3}-\mathrm{N}_{2} \mathrm{O}$. It is assumed that ion-neutralization does not produce hydrogen atoms in the presence of $\mathrm{N}_{2} \mathrm{O}$; and thus, the reduction in $G\left(\mathrm{H}_{2}\right)$ by addition of $\mathrm{N}_{2} \mathrm{O}$ is taken to be the yield of hydrogen from ion-neutralization. The two estimates are not necessarily directly comparable because the former refers to hydrogen atoms while the latter refers to $H_{2}$.

\subsubsection{Frèe Radical Processes}

Many important details of the mechanism by which $\mathrm{H}, \mathrm{NH}_{2}$ and $\mathrm{NH}$ lead to observed products are uncertain because of the lack of good specific rate data for many of the possible elementary processes.

Evidence from radiolysis of $\mathrm{NH}_{3}$ in the presence of radical-scavengers indicates that most of the observed yield of $\mathrm{H}_{2}$ results from processes involving free radicals. Non-radical processes yield only about 0.8 molecule of $\mathrm{H}_{2}$ per $100 \mathrm{eV}$ (table 2.2.1). At temperatures near $20^{\circ} \mathrm{C}$ radical sources of $\mathrm{H}_{2}$ include reactions (13'), (22), (24) and possibly (28) followed by (29). At higher temperatures (23) is also important (see sec. 3.2 .3 ). 
$\mathrm{N}_{2} \mathrm{H}_{4}$ is produced by combination of $\mathrm{NH}_{2}$ radicals but the observed yield is negligible in static systems except at very high dose rates $\left(>10^{20} \mathrm{eV} \cdot \mathrm{g}^{-1} \mathrm{~s}^{-1}\right)$ because of reactions (16), (22) and (22'). At high dose rates radical-hydrazine reactions compete less favorably with radical-radical reactions and $\mathrm{N}_{2} \mathrm{H}_{4}$ is observed in significant yields $(71-0216,69-0272,68-0101) . \mathrm{N}_{2} \mathrm{H}_{4}$ is also an important product in flow-systems (see sec. 3.2.6).

Reactions (27) and (29) are likely sources of $\mathrm{N}_{2}$ but their relative importance is uncertain. Competition between (27) and (28) is an important consideration but contradictory values have been reported for $k_{27} / k_{23}$. Volpi and Schiavello (62-0131) have found $\mathrm{NH}_{3}$ and $\mathrm{N}_{2}$ in a 2:1 ratio are the only products when $\mathrm{H}$ atoms from a microwave discharge flow into hydrazine vapor; and have concluded that $k_{27} \gg k_{28}$. Stief $(70-7065)$ on the other hand has reported $k_{28}=4 k_{27}$ on the basis of a study of the reaction of $\mathrm{H}$ atoms with isotopically labeled hydrazines. There is no apparent reason for this contradiction.

\subsection{Yields of Intermediates}

\subsubsection{Neutral Species}

Yields of intermediates involved in radiolysis of gaseous ammonia are summarized in tables 2.2.1 - 2.2.3. Values cited refer to the total yield of intermediates from both primary and secondary processes (i.e., from process 1 and from both primary and secondary reactions of the ions and excited molecules produced in processes 1 and 2 (table 2.1)). In ammonia, secondary reactions of ions include rapid ion-molecule reactions with $\mathrm{NH}_{3}$ and subsequent neutralization. Dissociation $(3,4,5)$ is apparently the only important reaction of excited ammonia molecules. Most of these yields have been inferred from studies with additives. Although the imaginative use of additives has been an invaluable source of information about mechanism, the significance of such information is often compromised by assumptions that must be made about the role of the additive.

A summary of values of $g(\mathrm{H})$ obtained with a variety of additives is given in table 2.2.2. Presumably in all cases the additive, $\mathrm{AH}$, reacts with $\mathrm{H}$ to produce $\mathrm{H}_{2}$,

$$
\mathrm{AH}+\mathrm{H} \rightarrow \mathrm{H}_{2}+\mathrm{A} .
$$

In most cases, the limiting value of $G\left(\mathrm{H}_{2}\right)$ calculated on the basis of energy absorbed in ammonia is assumed equal to $g(\mathrm{H})+g\left(\mathrm{H}_{2}\right)$. Results are in reasonably good agreement except for those obtained with propane as additive. Eyre and Smithies (70-0479) have recently shown that $G\left(\mathrm{H}_{2}\right)$ from mixtures of propane and ammonia decreases with dose at doses in excess of about $5 \times 10^{18}$ $\mathrm{eV} / \mathrm{g}$, presumably because of the build-up of propylene. They suggest that the lower values reported in earlier studies with mixtures of ammonia and propane $(68-0659,69-0326)$ may be low for that reason.

The value $g(\mathrm{H})=12.5$ reported by Jones and Sworski $(67-0270)$ is significantly higher than the other values in table 2.2.2. Their limiting value of $G\left(\mathrm{H}_{2}\right)$ is in agreement with that reported by Eyre and Smithies (70-0479) for the $\mathrm{NH}_{3}-\mathrm{N}_{2} \mathrm{H}_{4}$ system; but Jones and Sworski obtain a higher $g(\mathrm{H})$ because of a relatively large correction for the reactions $\mathrm{NH}_{2}+\mathrm{H} \rightarrow \mathrm{NH}_{3}$ and $\mathrm{N}_{2} \mathrm{H}_{3}+\mathrm{H} \rightarrow$ $\mathrm{N}_{2} \mathrm{H}_{4}$. The magnitude of this correction, which is obtained by a kinetic analysis of $G\left(\mathrm{H}_{2}\right)$, seems quite large in view of the relatively high rate for $\mathrm{H}+\mathrm{N}_{2} \mathrm{H}_{4} \rightarrow \mathrm{H}_{2}+\mathrm{N}_{2} \mathrm{H}_{3}$ (table 2.1). In any event, such a correction should be unnecessary for the other studies in table 2.2.2 except 69-0272 and 70-0216, because of the much lower dose rates involved (for dose rates see tables 3.1.1 and 3.1.2).

If the high value of Jones and Sworski and the low values obtained in the earlier studies with propane are disregarded, an average value of 10.4 is obtained for $g(\mathrm{H})$, and this is the preferred value. Table 2.2.2 does not include results obtained with $\mathrm{D}_{2}$ as additive. Jones and Sworski (670270) find $g(\mathrm{H})=12.5$ at 200 torr in good agreement with their results from $\mathrm{NH}_{3}-\mathrm{N}_{2} \mathrm{H}_{4}$; however, at 600 torr the analysis leads to $g(\mathrm{H})=90 \pm 66$. Studies of the $\mathrm{NH}_{3}-\mathrm{D}_{2}$ system by Johnson and Simic (68-0659) indicate a chain reaction is involved in the formation of $\mathrm{HD}$. 
$\mathrm{T}_{\mathrm{ABl} . \mathrm{E}}$ 2.2.1. Yields of intermediates in radiolysis of gaseous ammonia

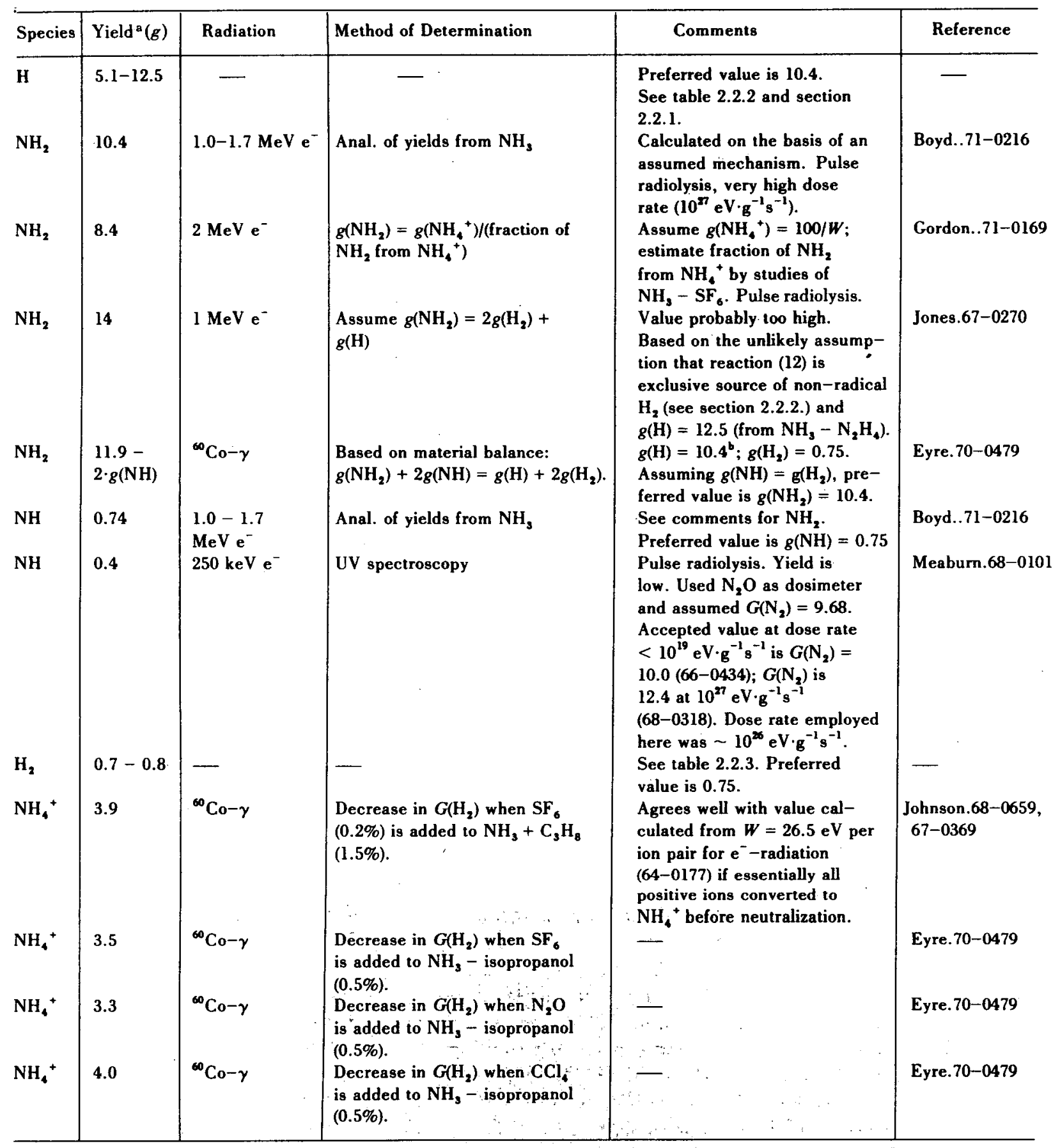

a. Unless otherwise indicated yields were measured at $\sim 20^{\circ} \mathrm{C}$ and $\sim 1$ atm. Yields are in ions, radicals or molecules per $100 \mathrm{eV}$ and refer to the total yield of the intermediate from reaction 1 and from primary and secondary reactions of the ions and excited states produced in reactions 1 and 2 (table 2.1 ).

b. Eyre and Smithies (70-0479) distinguish between $H$ atoms produced by ion neutralization and those produced by other reactions (such as 3 and 5). No such distinction is made in this papẹr and the value 10.4 refers to the total yield of $\mathrm{H}$ atoms (calculated from $g(\mathrm{H})$ and $g\left(\mathrm{e}^{-}\right)$values reported by Eyre and Smithies). 
TABLE 2.2.2. Yield of $H$-atoms:

\begin{tabular}{|c|c|c|c|c|}
\hline Yield $(g)$ & Radiation & Method & Comments & Reference \\
\hline 12.5 & $1 \mathrm{MeV} \mathrm{e}^{-}$ & Kinetic anal. of $G\left(\mathrm{H}_{2}\right)$ from $\mathrm{NH}_{3}-\mathrm{N}_{2} \mathrm{H}_{4}$. & $\begin{array}{l}\text { Assume } \mathrm{H}+\mathrm{N}_{2} \mathrm{H}_{4} \rightarrow \mathrm{H}_{2}+\mathrm{N}_{2} \mathrm{H}_{3} ; \\
\text { calculation of } g(\mathrm{H}) \text { allows for } \\
\mathrm{NH}_{2}+\mathrm{H} \rightarrow \mathrm{NH}_{3} \text { and } \mathrm{H}+\mathrm{N}_{2} \mathrm{H}_{3} \rightarrow \\
\mathrm{N}_{2} \mathrm{H}_{4} \cdot{ }^{b}\end{array}$ & Jones.67-0270 \\
\hline 10.4 & $\begin{array}{l}1.0-1.7 \\
\mathrm{MeV} \mathrm{e}^{-}\end{array}$ & $\begin{array}{l}\text { Kinetic anal. of product yields from } \\
\text { pure } \mathrm{NH}_{3} \text {. }\end{array}$ & $\begin{array}{l}\text { Pulse radiolysis. Very high } \\
\text { dose rate }\left(\geqslant 10^{20} \mathrm{eVg}^{-1} \mathrm{~s}^{-1}\right)\end{array}$ & Boyd..71-0168 \\
\hline 10.8 & ${ }^{60} \mathrm{Co}-\gamma$ & $\begin{array}{l}G\left(\mathrm{H}_{2}\right) \text { from } \mathrm{NH}_{3}-\mathrm{N}_{2} \mathrm{H}_{4} ; g(\mathrm{H})=G\left(\mathrm{H}_{2}\right)- \\
g\left(\mathrm{H}_{2}\right)=11.6-0.8 .^{c}\end{array}$ & $\begin{array}{l}\text { Assume all } \mathrm{H} \text { react with } \mathrm{N}_{2} \mathrm{H}_{4} \text { to } \\
\text { give } \mathrm{H}_{2} \text {. }\end{array}$ & Eyre. $70-0479$ \\
\hline 10.6 & ${ }^{60} \mathrm{Co}-\gamma$ & $G\left(\mathrm{H}_{2}\right)$ from $\mathrm{NH}_{3}-\mathrm{N}_{2} \mathrm{H}_{4}$ & As above. & Carstensen67-0701 \\
\hline 10.4 & ${ }^{60} \mathrm{Co}-\gamma$ & $\begin{array}{l}\text { Kinetic anal. of } G\left(\mathrm{H}_{2}\right) \text { from } \mathrm{NH}_{3}- \\
\text { methanol; } g(\mathrm{H})=G\left(\mathrm{H}_{2}\right)-g\left(\mathrm{H}_{2}\right) \\
=11.2-0.8 .^{c}\end{array}$ & $\begin{array}{l}\text { Assume } \mathrm{H}+\mathrm{CH}_{3} \mathrm{OH} \rightarrow \mathrm{H}_{2}+\mathrm{CH}_{2} \mathrm{C} \\
\text { scavenges all } \mathrm{H} \text {. }\end{array}$ & OH Eyre.70-0479 \\
\hline 9.5 & ${ }^{60} \mathrm{Co}-\gamma$ & $\begin{array}{l}\text { Kinetic anal. of } G\left(\mathrm{H}_{2}\right) \text { from } \\
\mathrm{NH}_{3} \text {-methanol. }\end{array}$ & As above. & Carstensen67-0701 \\
\hline 10.6 & ${ }^{60} \mathrm{Co}-\gamma$ & $\begin{array}{l}G\left(\mathrm{H}_{2}\right) \text { from } \mathrm{NH}_{3}-\text { cyclohexane; } \\
g(\mathrm{H})=G\left(\mathrm{H}_{2}\right)-g\left(\mathrm{H}_{2}\right) \\
=11.4-0.8\end{array}$ & $\begin{array}{l}\text { Assume } \mathrm{H}+\mathrm{C}_{6} \mathrm{H}_{12} \rightarrow \mathrm{H}_{2}+\mathrm{C}_{6} \mathrm{H}_{11} \\
\text { scavenges all } \mathrm{H} \text {. }\end{array}$ & Eyre.70-0479 \\
\hline 10.6 & ${ }^{60} \mathrm{Co}-\gamma$ & $\begin{array}{l}G\left(\mathrm{H}_{2}\right) \text { from } \mathrm{NH}_{3} \text {-isopropanol; } \\
g(\mathrm{H})=G\left(\mathrm{H}_{2}\right)-g\left(\mathrm{H}_{2}\right)= \\
11.4-0.8^{c}\end{array}$ & $\begin{array}{l}\text { Assume all } \mathrm{H} \text { react with } \\
\text { isopropanol to give } \mathrm{H}_{2}\end{array}$ & Eyre. 70-0479 \\
\hline 10.0 & ${ }^{60} \mathrm{Co}-\dot{\gamma}$ & $\begin{array}{l}G\left(\mathrm{H}_{2}\right) \text { from } \mathrm{NH}_{3}-\text { propare } \\
g(\mathrm{H})=G\left(\mathrm{H}_{2}\right)-g\left(\mathrm{H}_{2}\right) \\
10.8-0.8 .\end{array}$ & $\begin{array}{l}\text { Assume } \mathrm{H}+\mathrm{C}_{3} \mathrm{H}_{\mathrm{a}} \rightarrow \mathrm{H}_{2}+\mathrm{C}_{3} \mathrm{H}_{7} \\
\text { scavenges all } \mathrm{H} . \mathrm{G}\left(\mathrm{H}_{2}\right) \\
\text { decreases with dose above } \\
\sim 5 \times 10^{18} \mathrm{eV} / \mathrm{g} .\end{array}$ & Eyre.70-0479 \\
\hline 7.2 & ${ }^{60} \mathrm{Co}-\gamma$ & $\begin{array}{l}\text { As immediately above but } g(\mathrm{H})= \\
8.0-0.8^{\circ}\end{array}$ & $\begin{array}{l}\text { Lower value may be result of } \\
\text { dose effect (dose not stated). } \\
\text { See comment immediately above. }\end{array}$ & $\begin{array}{l}\text { Johnson.68-0659, } \\
67-0369\end{array}$ \\
\hline 5.1 & ${ }^{60} \mathrm{Co}-\gamma$ & $\begin{array}{l}\text { As immediately above but } g(\mathrm{H})= \\
5.8-0.7 .^{\mathrm{c}}\end{array}$ & See comment immediately above. & Nishikawa..69-0326 ${ }^{\mathrm{d}}$ \\
\hline 10.4 & $\begin{array}{l}1.0-1.7 \\
\mathrm{MeV} \mathrm{e}^{-}\end{array}$ & $\begin{array}{l}\text { Kinetic anal. of product yields from } \\
\text { pure } \mathrm{NH}_{3} \text {. }\end{array}$ & $\begin{array}{l}\text { Pulse radiolysis. Very high } \\
\text { dose rate }\left(\geqslant 10^{26} \mathrm{eV} \cdot \mathrm{g}^{-1} \mathrm{~s}^{-1}\right)\end{array}$ & Boyd..71-0216 \\
\hline
\end{tabular}

a. Unless otherwise indicated yields were measured at $\sim 20^{\circ} \mathrm{C}$ and $\sim 1$ atmosphere. Yields are in atoms per 100 $\mathrm{eV}$ and refer to the total yield of $\mathrm{H}$ from reaction $\mathrm{l}$ and from primary and secondary reactions of the ions and excited states produced in reactions 1 and 2 (table 2.1).

b. Correction based on kinetic analysis of $G\left(\mathrm{H}_{2}\right)$ data. Correction should be unnecessary for other work in this table except 71-0216.

c. See table 2.2.3.

d. See also $68-0505$. These authors have also used $\mathrm{C}_{3} \mathrm{H}_{8}$ to obtain $g(\mathrm{H})$ at high pressure $(68-0505,69-0026)$.

The limiting value of $G\left(\mathrm{H}_{2}\right)$ for pure ammonia at dose rate less than $10^{20} \mathrm{eV} \cdot \mathrm{g}^{-1} \mathrm{~s}^{-1}$ and at temperatures near $200^{\circ} \mathrm{C}$ (see section 3.2 .3 ) has also been used to estimate $g(\mathrm{H})(67-0270$, $68-0659,70-0479)$. It is assumed that when the limiting value of $G\left(\mathrm{H}_{2}\right)$ is reached, all $\mathrm{H}$ atoms react with either $\mathrm{NH}_{3}$ or $\mathrm{N}_{2} \mathrm{H}_{4}$ to produce $\mathrm{H}_{2}$. Depending upon the origin of the yield of nonscavengable $\mathrm{H}_{2}$, it is assumed that $G\left(\mathrm{H}_{2}\right)=g(\mathrm{H})+g\left(\mathrm{H}_{2}\right)$ or $G\left(\mathrm{H}_{2}\right)=g(\mathrm{H})+2 g\left(\mathrm{H}_{2}\right)$. Combination of the high temperature plateau value of $G\left(\mathrm{H}_{2}\right), 15$, with a $g\left(\mathrm{H}_{2}\right)$ of 0.8 (table 2.2.3.), leads to $g(\mathrm{H})=$ 13-14, a value significantly higher than has been obtained by any of the scavenger techniques. However, this estimate involves the important assumption that $\mathrm{H}_{2}$ is not produced by reaction of $\mathrm{N}_{2} \mathrm{H}_{3}$ or $\mathrm{N}_{2} \mathrm{H}_{2}$. Eyre and Smithies (70-0479) have suggested that thermal decomposition of $\mathrm{N}_{2} \mathrm{H}_{3}$ and/or $\mathrm{N}_{2} \mathrm{H}_{2}$ may increase with increasing temperature, and thus lead to an increased yield of $\mathrm{H}_{2}$. They assume that at temperatures near $20^{\circ} \mathrm{C}, \mathrm{N}_{2} \mathrm{H}_{3}$ and $\mathrm{N}_{2} \mathrm{H}_{2}$ lead to $\mathrm{N}_{2}$ but not to $\mathrm{H}_{2}$ (see table 2.1).

Additives known to act as efficient thermal hydrogen atom scavengers have been used to determine the yield of molecular hydrogen (see table 2.2.3). In general, the limiting yield of hydrogen in the presence of such scavengers can be used to obtain $g\left(\mathrm{H}_{2}\right)$ if proper allowance is 
TABLE 2.2.3. Primary yield of $\mathrm{H}_{2}{ }^{\circ}$

\begin{tabular}{|c|c|c|c|c|}
\hline Yield $(g)$ & Radiation & Method & Comments & Reference \\
\hline 0.81 & ${ }^{\infty} \mathrm{Co}-\gamma$ & $\begin{array}{l}\text { Limiting value of } G\left(\mathrm{H}_{2}\right) \text { in } \\
\text { presence of propylene. }\end{array}$ & $\begin{array}{l}\text { Assume }{ }^{b} \mathrm{H}+\mathrm{C}_{3} \mathrm{H}_{6} \rightarrow \mathrm{C}_{3} \mathrm{H}_{7}, \\
\mathrm{NH}_{2}+\mathrm{C}_{3} \mathrm{H}_{6} \rightarrow \mathrm{C}_{3} \mathrm{H}_{6} \mathrm{NH}_{2} . G\left(\mathrm{~N}_{2}\right) \\
\text { reduced from } 1.45 \text { to } \sim 0.3 .\end{array}$ & Eyre.70-0479 \\
\hline 0.80 & ${ }^{60} \mathrm{Co}-\gamma$ & As above. & $G\left(\mathrm{~N}_{2}\right)$ reduced from 1.9 to $\leqslant 0.3$ & Johnson.68-0659 \\
\hline $\begin{array}{l}0.70- \\
0.82\end{array}$ & ${ }^{60} \mathrm{Co}-\gamma$ & As above. & - & Nishikawa..67-0263 \\
\hline 0.84 & $250 \mathrm{keV} \mathrm{e}^{-}$ & As above. & Pulse radiolysis. & Meaburn.68-0101 \\
\hline 1.4 & Fast $\mathrm{e}^{-}$ & As above. & $\begin{array}{l}\text { High value may be result of } \\
\text { failure to correct for } \mathrm{H}_{2} \text { from } \\
\mathrm{C}_{3} \mathrm{H}_{6} \text {. }\end{array}$ & Sorokin.65-0523 \\
\hline 0.74 & $\begin{array}{l}1.0-1.7 \\
\mathrm{MeV} \mathrm{e}^{-}\end{array}$ & $\begin{array}{l}\text { Kinetic analysis of product yields } \\
\text { from pure } \mathrm{NH}_{3} \text {. }\end{array}$ & $\begin{array}{l}\text { Pulse radiolysis. Very high } \\
\text { dose rate }\left(\leqslant 10^{26} \mathrm{eV} \cdot \mathrm{g}^{-1} \mathrm{~s}^{-1}\right)\end{array}$ & Boyd..71-0216 \\
\hline 0.75 & $1 \mathrm{MeV}^{-}$ & $\begin{array}{l}\text { Limiting value of } G\left(\mathrm{H}_{2}\right) \text { in } \\
\text { presence of ethylene. }\end{array}$ & $\begin{array}{l}\text { Acts similarly to propylene. } \\
G\left(\mathrm{~N}_{2}\right) \text { reduced from } 1.5 \\
\text { to } \geqslant 0.6 .^{c}\end{array}$ & Jones $67-0270$ \\
\hline 0.74 & ${ }^{60} \mathrm{Co}-\gamma$ & As immediately above. & Also used $\mathrm{C}_{2} \mathrm{D}_{4}$ & $\begin{array}{l}\text { Nishikawa.68-005l, } \\
67-0263\end{array}$ \\
\hline 0.84 & ${ }^{60} \mathrm{Co}-\gamma$ & $\begin{array}{l}\text { Limiting value of } G\left(\mathrm{H}_{2}\right) \text { in } \\
\text { presence of benzene. }\end{array}$ & $\begin{array}{l}\text { Assume }{ }^{d} \mathrm{H}+\mathrm{C}_{6} \mathrm{H}_{6} \rightarrow \mathrm{C}_{6} \mathrm{H}_{7} \\
G\left(\mathrm{~N}_{2}\right) \text { reduced from } 1.45 \text { to } \\
\sim 0.3\end{array}$ & Eyre. $70-0479$ \\
\hline 1.0 & ${ }^{60} \mathrm{Co}-\gamma$ & As immediately above. & $\begin{array}{l}G\left(\mathrm{~N}_{2}\right) \text { reduced from } 1.4 \text { to } 1.0 \text {. } \\
\text { Aniline not detected. }\end{array}$ & Carstensen67-0701 \\
\hline 0.8 & ${ }^{60} \mathrm{Co}-\gamma$ & As immediately above. & - & Johnson.68-0659 \\
\hline
\end{tabular}

a. Unless otherwise indicated yields were measured at $\sim 20^{\circ} \mathrm{C}$ and $\sim$ one atmosphere. Yields are in molecules per $100 \mathrm{eV}$ and refer to total yield of $\mathrm{H}_{2}$ from reaction 1 and from primary and secondary reactions of the ions and excited states produced by reactions 1 and 2 (table 2.1 ).

b. Charge exchange between $\mathrm{NH}_{3}{ }^{+}$and $\mathrm{C}_{3} \mathrm{H}_{6}$ is energetically possible but should be negligible at concentrations involved. Proton transfer from $\mathrm{NH}_{4}{ }^{+}$to $\mathrm{C}_{3} \mathrm{H}_{6}$ ruled out on basis of proton affinities: $\sim 9.2$ and $6.6 \mathrm{eV}$ for $\mathrm{NH}_{3}$ and $\mathrm{C}_{3} \mathrm{H}_{6}$, respectively (62-9017).

c. $\mathrm{N}_{2}$ determined mass spectrometrically. Presence of $\mathrm{C}_{2} \mathrm{H}_{4}$ led to analytical difficulties.

d. Charge exchange between $\mathrm{NH}_{3}{ }^{+}$and $\mathrm{C}_{6} \mathrm{H}_{6}$ is energetically possible but should be negligible at concentrations involved. Proton transfer from $\mathrm{NH}_{4}{ }^{+}$is probably ruled out on basis of proton affinities: $\sim 9.2$ and $\leqslant 6.3 \mathrm{eV}$ (62-9017).

made for energy absorbed in the additive. Results with a variety of additives are in good agreement and lead to $g\left(\mathrm{H}_{2}\right)=0.75$.

Relatively few values of $g\left(\mathrm{NH}_{2}\right)$ have been reported. Gordon, Mulac, and Nangia (71-0169) estimate $g\left(\mathrm{NH}_{2}\right)=8.4$ from $g\left(\mathrm{NH}_{4}^{+}\right)$and the fraction of $\mathrm{NH}_{2}$ produced by neutralization of $\mathrm{NH}_{4}^{+}$. They assume $g\left(\mathrm{NH}_{4}{ }^{+}\right)=100 / W(W$ is the energy in $\mathrm{eV}$ to produce an ion pair) and estimate the fraction of $\mathrm{NH}_{2}$ produced by neutralization of $\mathrm{NH}_{4}^{+}$from a comparison of results of irradiation of pure $\mathrm{NH}_{3}$ and of $\mathrm{NH}_{3}$ in the presence of $\mathrm{SF}_{6}$. Jones and Sworski $(67-0270)$ have suggested $g\left(\mathrm{NH}_{2}\right)$ $=g(\mathrm{H})+2 g\left(\mathrm{H}_{2}\right)$ on the basis of the unlikely assumption that non-radical $\mathrm{H}_{2}$ arises exclusively via reaction (12). As noted earlier (sec. 2.1.1) studies of mixtures of $\mathrm{NH}_{3}$ and $\mathrm{CCl}_{4}$ indicate $g(12) \sim 0.1$ (68-0051) whereas $g\left(\mathrm{H}_{2}\right)=0.75$. Reaction (4) probably accounts for a significant fraction of nonscavengable $\mathrm{H}_{2}$. In photochemistry $12-14 \%$ of the dissociation at 147 and $123.6 \mathrm{~nm}(64-7003$, $62-0132$ ) is attributed to (4),

$$
\text { (4) } \mathrm{NH}_{3} * \rightarrow \mathrm{NH}+\mathrm{H}_{2}
$$

and NH has been observed spectroscopically by Meaburn and Gordon (68-0101) in pulse radiolysis of $\mathrm{NH}_{3}$. Meaburn and Gordon estimate $g(\mathrm{NH}) \sim 0.4$, but this is probably low because of an error in dosimetry (table 2.2.1). On the basis of material balance one expects $g\left(\mathrm{NH}_{2}\right)=g(\mathrm{H})+2 g\left(\mathrm{H}_{2}\right)-$ $2 g(\mathrm{NH})$. The best assumption seems to be that $g(\mathrm{NH}) \cong g\left(\mathrm{H}_{2}\right)$ and this leads to a preferred value of 10.4 for $g\left(\mathrm{NH}_{2}\right)$. 
More recently Boyd, Willis, and Miller (71-0216) have shown that their product yields from radiolysis of pure ammonia with single pulses of electrons $(1.0-1.7 \mathrm{MeV})$ at very high dose rate $\left(\geqslant 10^{26} \mathrm{eV} \cdot \mathrm{g}^{-1} \mathrm{~s}^{-1}\right)$ are constant with $g(\mathrm{H})=g\left(\mathrm{NH}_{2}\right)=10.4$ and $g\left(\mathrm{H}_{2}\right)=g(\mathrm{NH})=0.74$. At the high dose rates employed, radical-product reactions are not significant and they assume the following mechanism:

(13) $\mathrm{NH}_{2}+\mathrm{H} \rightarrow \mathrm{NH}_{3}$

(13') $\mathrm{NH}_{2}+\mathrm{H} \rightarrow \mathrm{NH}+\mathrm{H}_{2}$

(14) $\mathrm{NH}_{2}+\mathrm{NH}_{2} \rightarrow \mathrm{N}_{2} \mathrm{H}_{4}$

(15) $\mathrm{NH}_{2}+\mathrm{NH}_{2} \rightarrow \mathrm{NH}+\mathrm{NH}_{3}$

(18) $\mathrm{NH}+\mathrm{NH} \rightarrow \mathrm{N}_{2} \mathrm{H}_{2} * \rightarrow \mathrm{N}_{2}+\mathrm{H}_{2}$

(24) $\mathrm{H}+\mathrm{H} \rightarrow \mathrm{H}_{2}$

They take $k_{14}+k_{15} \cong 2.3 \times 10^{9} \mathrm{dm}^{3} \mathrm{~mol}^{-1} \mathrm{~s}^{-1}$ and calculate, using a computer program based on that of Schmidt (66-8024), $G\left(\mathrm{~N}_{2} \mathrm{H}_{4}\right), G\left(\mathrm{H}_{2}\right)$ and $G\left(\mathrm{~N}_{2}\right)$ for various values of $k_{14} / k_{15}$ and $k_{13}, k_{13^{\prime}}, k_{18}$ and $k_{24} . G\left(\mathrm{~N}_{2} \mathrm{H}_{4}\right)$ depends mainly upon $k_{13}$ and $k_{14}$ and $G\left(\mathrm{H}_{2}\right)$ depends primarily upon $k_{13}$, for fixed values of $k_{13}$ and $k_{14}$.

Agreement between calculated and observed product yields is achieved for very reasonable values of the various specific rates $\left(k_{13}=1.8 \times 10^{10}, k_{13^{\prime}}=2.9 \times 10^{9}, k_{14}=1.8 \times 10^{9}, k_{15}=5 \times 10^{8}\right.$, $k_{18}=5 \times 10^{10}$ and $\left.k_{24}=1.6 \times 10^{8} \mathrm{dm}^{3} \mathrm{~mol}^{-1} \mathrm{~s}^{-1}\right)$. These results represent a re-examination and extension of an earlier study (69-0272).

\subsubsection{Yields of Ionic Species}

Johnson and Simic $(68-0659,67-0369)$ have determined $g\left(\mathrm{NH}_{4}{ }^{+}\right)$from the reduction by $\mathrm{SF}_{6}$ of $G\left(\mathrm{H}_{2}\right)$ from mixtures of $\mathrm{NH}_{3}$ and propane. $G\left(\mathrm{H}_{2}\right)$ is 8.0 for $\mathrm{NH}_{3}$ containing 1.5 mole percent propane. Addition of 0.2 mole percent $\mathrm{SF}_{6}$ reduces $G\left(\mathrm{H}_{2}\right)$ to 4.1 . $\mathrm{SF}_{6}$ reacts rapidly with thermal electrons (66-9159) but only very slowly with hydrogen atoms and free radicals generally (670093, 66-0249, 64-9016). Therefore, the observed reduction in $G\left(\mathrm{H}_{2}\right)$ is attributed to modification of the neutralization process. In $\mathrm{NH}_{3}-\mathrm{C}_{3} \mathrm{H}_{8}$, neutralization of $\mathrm{NH}_{4}{ }^{+}$is assumed to proceed via (11) and (12) whereas in the presence of $\mathrm{SF}_{6}, \mathrm{NH}_{4}{ }^{+}$is neutralized by $\mathrm{SF}_{6}{ }^{-}$. This latter process is assumed not to produce $\mathrm{H}$ or $\mathrm{H}_{2}$ and hence $\Delta G\left(\mathrm{H}_{2}\right)=g\left(\mathrm{NH}_{4}{ }^{+}\right)$. The value obtained, 3.9, agrees well with $g\left(\mathrm{NH}_{4}{ }^{+}\right)$calculated from $W=26.5 \mathrm{eV}$ per ion pair (64-0177) assuming essentially all positive ions are converted to $\mathrm{NH}_{4}{ }^{+}$before neutralization.

Nishikawa, Kuroda, and Matsuura (69-0326) also have studied the $\mathrm{NH}_{3}-\mathrm{C}_{3} \mathrm{H}_{8}-\mathrm{SF}_{6}$ system; but while results are qualitatively similar, they find the decrease in $G\left(\mathrm{H}_{2}\right), \Delta G\left(\mathrm{H}_{2}\right)$ is only about 2 . Their value of $G\left(\mathrm{H}_{2}\right)$ for the ternary system is about the same, 3.8, as that reported by Johnson and Simic but $G\left(\mathrm{H}_{2}\right)$ for $\mathrm{NH}_{3}-\mathrm{C}_{3} \mathrm{H}_{8}$ is significantly lower.

Johnson and Simic (68-0659) have investigated the system $\mathrm{NH}_{3}-\mathrm{C}_{3} \mathrm{H}_{8}-\mathrm{N}_{2} \mathrm{O}$ which might be expected to be similar to the $\mathrm{NH}_{3}-\mathrm{C}_{3} \mathrm{H}_{8}-\mathrm{SF}_{6}$ system since both $\mathrm{N}_{2} \mathrm{O}$ and $\mathrm{SF}_{6}$ are good electron scavengers and poor $\mathrm{H}$-atom scavengers. Although addition of $\mathrm{N}_{2} \mathrm{O}$ to mixtures of $\mathrm{NH}_{3}$ and $\mathrm{C}_{3} \mathrm{H}_{8}$ does reduce $G\left(\mathrm{H}_{2}\right)$, the decrease, 3.0, is less than that produced by addition of $\mathrm{SF}_{6}, 3.9$. Nishikawa, Kuroda, and Matsuura (69-0326) have also studied this system and report similar results.

More recently Eyre and Smithies (70-0479) have carried out similar studies on mixtures of ammonia and isopropanol $(0.5 \%) . G\left(\mathrm{H}_{2}\right)$ is 11.4 for this system and introduction of $\mathrm{SF}_{6}, \mathrm{~N}_{2} \mathrm{O}$ or $\mathrm{CCl}_{4}$ reduces $G\left(\mathrm{H}_{2}\right)$ to limiting values which are respectively $7.9,8.1$ and 7.4. They conclude that $\Delta G\left(\mathrm{H}_{2}\right)=g\left(\mathrm{NH}_{4}{ }^{+}\right)$. Using the weighted mean of $\Delta G\left(\mathrm{H}_{2}\right)$ they obtain $g\left(\mathrm{NH}_{4}{ }^{+}\right)=3.4$. Presumably, the yield of $\mathbf{H}$ from sources other than ion-neutralization is then 7.0.

\section{Product Yields}

$\mathrm{H}_{2}, \mathrm{~N}_{2}$ and $\mathrm{N}_{2} \mathrm{H}_{4}$ are the products observed in radiolysis of gaseous ammonia but yields depend upon a number of parameters such as temperature, pressure and dose rate. Yields at 
approximately $20^{\circ} \mathrm{C}$ and one atmosphere pressure are summarized in section 3.1 , and the influence of various parameters is discussed in 3.2 .

\subsection{Product Yields for Radiolysis Under Static Conditions at $\sim 20^{\circ} \mathrm{C}$ and $\sim 1$ Atmosphere}

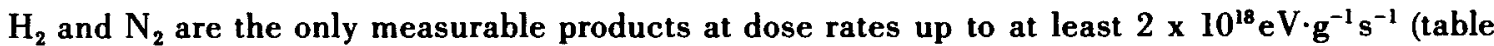
3.1.1); $G\left(\mathrm{H}_{2}\right)=5.0 \pm 1.0$ and $G\left(\mathrm{~N}_{2}\right)=1.7 \pm 0.3$. Presumably, the steady-state concentration of hydrazine is kept very low because of radical-hydrazine reactions (see sec. 2.1.2).

At very high dose rates $\left(\geqslant 10^{26} \mathrm{eV} \cdot \mathrm{g}^{-1} \mathrm{~s}^{-1}\right)$ hydrazine is produced in significant yield in static systems (71-0216, 69-0272) because radical-product reactions do not compete effectively with radical-radical reactions. Hydrazine is also a product in flow systems (see sec. 3.2.6).

In all cases the total dose was sufficiently low to preclude variations in product yields associated with high conversion (see sec. 3.2 .1 ). Indeed, the only obvious variables are dose rate and the LET (linear energy transfer), of the radiation. Both of these factors may contribute to the relatively large scatter in yields but it is clear from table 3.1.2 that they alone are not responsible. Other probable contributing factors include the presence of trace impurities and problems in dosimetry. The neutralization process in particular should be quite sensitive to trace impurities, the presence of which would probably lead to low yields (see sec. 2.1.1). Most of the results summarized in this sec. are based on dosimetry with nitrous oxide. Problems associated with gas phase dosimetry in general $(71-0062,67-0546,71-0179)$ and the nitrous oxide dosimeter in particluar $(71-0062,68-0318,67-0027,66-0434,61-0103)$ have been discussed elsewhere.

TABI.E 3.1.1. Product yields from radiolysis of gaseous ammonia with various radiations under static conditions at $\sim 20^{\circ} \mathrm{C}$ and $\sim 1$ atm

\begin{tabular}{|c|c|c|c|c|c|c|c|}
\hline Radiation & $G\left(-\mathrm{NH}_{3}\right)$ & $G\left(\mathrm{H}_{2}\right)$ & $G\left(\mathrm{~N}_{2}\right)$ & $G\left(\mathrm{~N}_{2} \mathrm{H}_{4}\right)$ & $\begin{array}{c}\text { Dose Rate } \\
\left(\mathrm{eV} \cdot \mathrm{g}^{-1} \mathrm{~s}^{-1}\right)\end{array}$ & Comments & Reference \\
\hline $1 \mathrm{MeV} \mathrm{e}^{-}$ & 3.0 & 4.5 & 1.5 & 0.0 & $2 \times 10^{10 b}$ & $\begin{array}{l}\text { Yields depend upon dose } \\
\text { rate. See section } 3.2 .2\end{array}$ & Jones. $67-0270$ \\
\hline $1.0-1.7 \mathrm{MeV} \mathrm{e}^{-}$ & - & 3.6 & 1.0 & $0.58^{\circ}$ & $\begin{array}{l}2 \times 10^{26} \text { and } \\
2 \times 10^{27 d}\end{array}$ & Pulse radiolysis. & $\begin{array}{l}\text { Boyd..71-0216 and } \\
\text { Willis..69-0272 }\end{array}$ \\
\hline$\sim 250 \mathrm{keV} \mathrm{e}^{-}$ & - & $2.3^{\circ}$ & $0.68^{\circ}$ & $0.07^{\mathrm{e}}$ & $\begin{array}{l}\sim 10^{20}\left(4.0 \times 10^{18}\right. \\
\mathrm{eV} / \text { pulse }) .\end{array}$ & Pulse radiolysis. & Meaburn.68-0101 \\
\hline${ }^{80} \mathrm{Co}-\gamma$ & $\begin{array}{l}2.7- \\
4.7\end{array}$ & $\begin{array}{l}4.1- \\
7.0\end{array}$ & $\begin{array}{l}1.4- \\
2.3\end{array}$ & $0.0-0.001$ & - & See table 3.1.2. & - \\
\hline${ }^{1} \mathrm{H}^{+}(0.8 \mathrm{MeV})$ & 4.0 & 6.0 & 2.0 & 0.0 & & $\begin{array}{l}\text { Yields depend on dose } \\
\text { rate. See section } 3.2 .2\end{array}$ & Horscroft64-0174 \\
\hline${ }^{2} \mathrm{H}^{+}(2 \mathrm{MeV})$ & - & - & - & 0.5 & not reported & $\begin{array}{l}\text { No attempt to measure } \\
G\left(\mathrm{H}_{2}\right) \text { ar } G\left(\mathrm{~N}_{2}\right)\end{array}$ & Lampe...63-0098 \\
\hline${ }^{4} \mathrm{He}^{2+}$ & $\begin{array}{l}3.0- \\
4.2^{2}\end{array}$ & - & - & 一 & - & See table 3.1 .3 & - \\
\hline $\begin{array}{l}\text { Reactor } \\
(\gamma+n)\end{array}$ & 3.8 & 5.7 & 1.9 & - & - & - & Dolle58-0051 \\
\hline
\end{tabular}

a. For yields at other temperatures and pressures see section 3.2 .

b. $\mathrm{N}_{2} \mathrm{O}$ dosimetry; $G\left(\mathrm{~N}_{2}\right)=10.0(66-0434)$.

c. $\mathrm{N}_{2} \mathrm{H}_{4}$ is a significant product in static system only when dose rate is high enough to reduce the importance of radical $-\mathrm{N}_{2} \mathrm{H}_{4}$ reactions.

d. $\mathrm{N}_{2} \mathrm{O}$ dosimetry; $G\left(\mathrm{~N}_{2}\right)=12.4$. Value obtained by adiabatic calorimetry (68-0318). Probably applies only to very high dose rates.

e. These values are probably low because they are based upon $\mathrm{N}_{2} \mathrm{O}$ dosimetry with $G\left(\mathrm{~N}_{2}\right)=9.68$. Generally accepted value is $G\left(\mathrm{~N}_{2}\right)=10$ for dose rates less than about $10^{19} \mathrm{eV} \cdot \mathrm{g}^{-1} \mathrm{~s}^{-1}$. Value may be higher at higher dose rates (see $d$ above). The dose rate is estimated from the dose per pulse on the basis of a cell volume of 0.68 liters and a pulse duration of $\sim 40 \mathrm{~ns}$.

f. Dosimetry based on charge collection; value in $\mathrm{eV} \cdot \mathrm{g}^{-1} \mathrm{~s}^{-1}$ involves estimate of effective volume. This is lowest dose rate employed.

g. Most yields originally reported as molecules per ion pair $(M / N)$; these have been converted to $G$ assuming $W$ $=30.5 \mathrm{eV}$ per ion pair in $\mathrm{NH}_{3}$ for ${ }^{4} \mathrm{He}^{2+}$ radiation (53-0008). 
Jungers (36-0001) has studied the relative rates of decomposition of $\mathrm{NH}_{3}$ and $\mathrm{ND}_{3}$ by ${ }^{4} \mathrm{He}^{2+}$ radiation at 525 torr. At $20^{\circ} \mathrm{C}$, the ratio $G\left(-\mathrm{NH}_{3}\right): G\left(-\mathrm{ND}_{3}\right)$ is 1.27 . Absolute yields were not reported.

TABLE 3.1.2: Product yields for gamma radiolysis at $-20^{\circ} \mathrm{C}$ and -1 atm

\begin{tabular}{|c|c|c|c|c|c|c|}
\hline$G\left(-\mathrm{NH}_{3}\right)$ & $G\left(\mathrm{H}_{2}\right)$ & $G\left(\mathrm{~N}_{2}\right)$ & $\begin{array}{c}G\left(\mathrm{~N}_{2} \mathrm{H}_{4}\right) \\
\cdots\end{array}$ & $\begin{array}{l}\text { Dose Rate } \\
\left(\mathrm{eV} \cdot \mathrm{g}^{-1} \mathrm{~s}^{-1}\right)\end{array}$ & Dosimetry & Reference \\
\hline 4.7 & 7.0 & 2.3 & $\begin{array}{l}0.0005- \\
0.001\end{array}$ & $1.5 \times 10^{16}$ & Not stated. & Sorokin.64-1757 \\
\hline $4.2(4.0)^{b}$ & $6.3(6.0)^{b}$ & - & & $7.0 \times 10^{15}$ & $\mathrm{~N}_{2} \mathrm{O} ; G\left(\mathrm{~N}_{2}\right)=10.6$ & Anderson.67-0546 \\
\hline 4.0 & 6.0 & 2.0 & & $6.0 \times 10^{16}$ & $\mathrm{~N}_{2} \mathrm{O} ; G\left(\mathrm{~N}_{2}\right)=10.0$ & Kazanjian.68-0555 \\
\hline 3.8 & 5.7 & 1.9 & & $1.4 \times 10^{16}$ & $\mathrm{~N}_{2} \mathrm{O} ; G\left(\mathrm{~N}_{2}\right)=10.0$ & Johnson. $68-0659^{\circ}$ \\
\hline (3.3) & $(4.9)$ & (1.6) & - & $\left(5 \times 10^{14}\right)$ & Fricke. & Dolle $58-0051$ \\
\hline 3.0 & 4.5 & 1.5 & -. & $6.9 \times 10^{15}$ & $\mathrm{C}_{2} \mathrm{H}_{4} ; G\left(\mathrm{H}_{2}\right)=1.2$ & Buchanan.70-0134 \\
\hline 2.9 & 4.3 & 1.4 & 0.0 & $2 \times 10^{15}$ & $\begin{array}{l}\mathrm{N}_{2} \mathrm{O} ; G\left(\mathrm{~N}_{2}\right)+G\left(\mathrm{O}_{2}\right) \\
=12.0 .\end{array}$ & Nishikawa.68-0051 \\
\hline 2.7 & 4.1 & 1.4 & 0.0 & $5 \times 10^{14}$ & $\mathrm{~N}_{2} \mathrm{O} ; G\left(\mathrm{~N}_{2}\right)=10.0$ & Carstensen67-0701 \\
\hline 2.7 & 4.1 & - & - & Not given. & - & Nishikawa..68-0505 \\
\hline 2.7 & 4.1 & 1.4 & - & $9 \times 10^{14}$ & $\mathrm{~N}_{2} \mathrm{O} ; G\left(\mathrm{~N}_{2}\right)=10.0$ & Nishikawa..69-0326 \\
\hline 2.9 & 4.4 & 1.4 & $\leqslant 0.005$ & $3 \times 10^{15}$ & $\mathrm{~N}_{2} \mathrm{O} ; G\left(\mathrm{~N}_{2}\right)=10.0$ & Eyre.70-0479 \\
\hline
\end{tabular}

a. Results from $63-0165$ excluded as unreliable.

b. Corrected on the basis that $G\left(\mathrm{~N}_{2}\right)=10.0$ rather than $10.6(66-0434)$.

c. See also $67-0369$.

d. Without wall corrections; values are of questionable validity.

$\mathrm{T}_{\mathrm{ABI} . \mathrm{E}}$ 3.1.3. Yields for radiolysis with alpha particles at $\sim 20^{\circ} \mathrm{C}$ and $\sim 1 \mathrm{~atm}$

\begin{tabular}{|c|c|c|c|c|c|c|}
\hline Source & $G\left(-\mathrm{NH}_{3}\right)$ & $G\left(\mathrm{H}_{2}\right)$ & $G\left(\mathrm{~N}_{2}\right)$ & $\begin{array}{l}\text { Dose Rate } \\
\left(e V \cdot g^{-1} s^{-1}\right)^{b}\end{array}$ & Comments & Reference \\
\hline Rn & $3.0^{\mathrm{e}}$ & $4.5^{c}$ & $1.5^{\circ}$ & - & $\begin{array}{l}\text { Used }{ }^{4} \mathrm{He}^{2+} \text { sources of } \\
\text { comparable strength } \\
\text { to those used by Luyckx } \\
(34-0003)\end{array}$ & Wourtzel 19-0001 \\
\hline Rn & 3.8 & 一 & - & - & $\begin{array}{l}\text { See immediately above. Yield } \\
\text { depends upon dose rate; value } \\
\text { given obtained by extrapolation } \\
\text { to zero dose rate. }\end{array}$ & Jungers $32-0002$ \\
\hline $\mathbf{R n}$ & 4.2 & - & - & $\begin{array}{l}\sim(0.1-5) \times \\
10^{16}\end{array}$ & $\begin{array}{l}\text { Yield depends upon dose rate; } \\
\text { value given obtained by } \\
\text { extrapolation to zero dose } \\
\text { rate. }\end{array}$ & Luyckx34-0003 \\
\hline Ra & 3.6 & - & - & $\sim 5 \times 10^{13}$ & - & Essex.34-0001 \\
\hline Ra & 3.6 & - & - & $-6 \times 10^{14}$ & - & Burtt.57-0018 \\
\hline${ }^{210} \mathrm{Po}$ & 3.5 & 5.2 & 1.7 & $7.6 \times 10^{17}$ & - & Kazanjian.68-0555 \\
\hline
\end{tabular}

a. In all studies except $68^{\prime}-0555$, yields were originally reported as molecules per ion pair $(M / N)$. These have been converted to $G$ assuming. $W=30.5 \mathrm{eV}$ per ion pair for ${ }^{4} \mathrm{He}^{2+}$ radiation (53-0008).

b. In all studies except $68-0555$ dose rates were not reported as such. Values were calculated from data given. In 68- $0555 \mathrm{~N}_{2} \mathrm{O}$ was used as dosimeter and $G\left(\mathrm{~N}_{2}\right)$ was assumed to be the same as for ${ }^{60} \mathrm{Co}-\gamma(10.0)$. Recent work of Sears (69-0085) supports this assumption. Dose rates for other studies have been estimated from original data and $W=30.5 \mathrm{eV}$ per ion pair.

c. Original data leads to $G\left(-\mathrm{NH}_{3}\right)=2.6$. Values cited here are based on recalculations by Jungers $(32-0002)$. 


\subsection{Effect of Various Parameters}

\subsubsection{Dose}

At dose rates such that $\mathrm{H}_{2}$ and $\mathrm{N}_{2}$ are the only products, $G\left(\mathrm{H}_{2}\right)$ and $G\left(\mathrm{~N}_{2}\right)$ are independent of total dose up to at least $8 \times 10^{22} \mathrm{eV} / \mathrm{g}$ (table 3.2.1). At very high conversions, yields should decrease because of $\mathrm{NH}_{2}+\mathrm{H}_{2} \rightarrow \mathrm{NH}_{3}+\mathrm{H}(64-0174,32-0002)$. The inhibiting effect of $\mathrm{H}_{2}$ has been observed in photochemical studies of $\mathrm{NH}_{3}(55-7001,44-7000)$.

At dose rates of the order of $10^{26} \mathrm{eV} \cdot \mathrm{g}^{-1} \mathrm{~s}^{-1}, \mathrm{~N}_{2} \mathrm{H}_{4}$ is a product and because $\mathrm{N}_{2} \mathrm{H}_{4}$ reacts with $\mathrm{H}$ and $\mathrm{NH}_{2}$, product yields may be independent of dose over a more limited range. Available data indicate independence of dose extends at least up to $6 \times 10^{20} \mathrm{eV} / \mathrm{g}\left(\right.$ at $\left.10^{27} \mathrm{eV} \cdot \mathrm{g}^{-1} \mathrm{~s}^{-1}\right)(69-0272)$. At these high dose rates the total dose is delivered as a series of pulses of very short duration (50$100 \mathrm{~ns})$.

TABLE 3.2.1. Effect of dose

\begin{tabular}{l|l|l|l}
\hline Radiation & Effect of $G\left(-\mathrm{NH}_{3}\right)^{*}$ & Max. Dose $(\mathrm{eV} / \mathrm{g})$ & Reference \\
\hline Fast $\mathrm{e}^{-}$ & none & $8 \times 10^{22 \mathrm{~b}}$ & Sorokin.65-0523 \\
$\mathrm{Fast}^{-}(1 \mathrm{MeV})$ & none & $4.5 \times 10^{21}$ & Jones.67-0270 \\
${ }^{60} \mathrm{Co}^{-} \gamma$ & none & $3 \times 10^{22}$ & Kazanjian.68-0555 \\
${ }^{4} \mathrm{He}^{2+}\left({ }^{210} \mathrm{Po}\right)$ & none & $6 \times 10^{22}$ & Kazanjian.68-0555 \\
${ }^{1} \mathrm{H}^{+}(0.8 \mathrm{MeV})$ & none & $6 \times 10^{21} \mathrm{eV}$ totally & Horscroft $64-0174$ \\
& & absorbed in $0.5 \mathrm{~cm}^{3}$. & \\
\hline
\end{tabular}

a. At dose rates employed $\mathrm{N}_{2}$ and $\mathrm{H}_{2}$ were the only products observed. Relevant dose rates can be found in tables 3.1.1 and 3.1.2.

b. Corresponds to about $5 \%$ conversion.

c. See also 69-0272 for results with fast $\mathrm{e}^{-}$at very high dose rate $\left(10^{27} \mathrm{eV} \cdot \mathrm{g}^{-1} \mathrm{~s}^{-1}\right)$.

d. See also 58-0051, 64-1757, 67-0701, 70-0134.

\subsubsection{Dose Rate}

At pressures near one atmosphere $G\left(-\mathrm{NH}_{3}\right)$ decreases with increasing dose rate (table 3.2.2) and the magnitude of the effect decreases with decreasing pressure (67-0271, 34-0003).

Sorokin and Pshezhetskii (65-0523) report $G\left(-\mathrm{NH}_{3}\right)$ independent of intensity; however, their investigation was limited to a relatively small (eight-fold) variation in dose rate. The results of Jones, Sworski and Williams (67-0271) obtained under similar conditions, but for a much wider $\left(100-\right.$ fold) variation in dose rate, indicate that $G\left(-\mathrm{NH}_{3}\right)$ should change only by about $10 \%$ over the range employed by Sorokin and Pshezhetskii.

Burtt and Baurer (55-0010) and Burtt and Zahlen (57-0018) have reported $G\left(-\mathrm{NH}_{3}\right)$ increases with increasing intensity at 200 torr but the intensities were much lower than are usually encountered (table 3.2.2).

The observed decrease in $G\left(-\mathrm{NH}_{3}\right)$ with increasing dose rate has not been satisfactorily explained. No effect is expected on the basis of the simple mechanism discussed in sections 2.1.1 and 2.1.2. That mechanism assumes that ions and excited neutrals produced in the early stages of radiolyisis undergo reactions that lead principally to $\mathrm{NH}_{2}, \mathrm{H}, \mathrm{NH}$, and $\mathrm{H}_{2}$. The radicals in turn react with each other and with other intermediates such as $\mathrm{N}_{2} \mathrm{H}_{4}$ and $\mathrm{N}_{2} \mathrm{H}_{3}$ to give the observed products.

If reaction (23) is included in the mechanism, $G\left(-\mathrm{NH}_{3}\right)$ would

$$
\text { (23) } \mathrm{H}+\mathrm{NH}_{3} \rightarrow \mathrm{H}_{2}+\mathrm{NH}_{2}
$$

be expected to decrease with increasing intensity. The specific rate of (23) has not been accurately measured but estimates of $5 \mathrm{dm}^{3} \mathrm{~mol}^{-1} \mathrm{~s}^{-1}(65-0555)$ and $200 \mathrm{dm}^{3} \mathrm{~mol}^{-1} \mathrm{~s}^{-1}(69-0272)$ have been reported for temperatures near $20^{\circ} \mathrm{C}$. If $k_{23}$ is in fact as high as $200 \mathrm{dm}^{3} \mathrm{~mol}^{-1} \mathrm{~s}^{-1}$, reaction (23) 
TABlE 3.2.2. Effect of dose rates at $-23^{\circ} \mathrm{C}$

\begin{tabular}{|c|c|c|c|}
\hline Radiation: & Dose Rate $\left(\mathrm{eV} . \mathrm{cm}^{-3} \mathrm{~s}^{-1}\right)$ & Effect on $G\left(-\mathrm{NH}_{2}\right)$ & Reference \\
\hline $1 \mathrm{MeV}^{-}$ & $6.5 \rightarrow 650 \times 10^{14 b}$ & $\begin{array}{l}\text { Decréases from } 3.5 \text { to } 2.6 \text { at } 700 \text { torr; } \\
\text { negligible effect at } 200 \text { torr. }\end{array}$ & Jones..67-0271 \\
\hline Fast $\mathbf{e}^{-\bullet}$ & $\begin{array}{l}8 \rightarrow 60 \times 10^{14} \\
4.0 \times 10^{14} \rightarrow 9.8 \times 10^{19}\end{array}$ & $\begin{array}{l}\text { None. } \\
\text { Decreases from } 4.0 \text { to } 1.6 \text { at } 300 \text { torr (only } \\
P \text { studied). } G \text { appears to be leveling off } \\
\text { at } \sim 1.6 \text {. }\end{array}$ & $\begin{array}{l}\text { Sorokin.65-0523 } \\
\text { Horscroft } 64-0174\end{array}$ \\
\hline${ }^{4} \mathrm{He}^{2+}$ & $10^{12} \rightarrow 5 \times 10^{13}$ & $\begin{array}{l}\text { Decreases } 30 \% \text { at } 450-700 \text { torr; effect } \\
\text { diminishes below } 450 \text { and is negligible below } \\
\sim 140 \text { torr. }\end{array}$ & Luyckx34-0003" \\
\hline${ }^{4} \mathrm{He}^{24}$ & $1.7 \rightarrow 30 \times 10^{10}$ & Increases from 2.4 to 3.4 at 200 torr. & $\begin{array}{r}\text { Burtt.55-0010, } \\
57-0018\end{array}$ \\
\hline
\end{tabular}

a. No results from a single laboratory for ${ }^{\infty} \mathrm{Co}-\mathrm{y}$ radiation.

b. Originally reported in $\mathrm{eV} / \mathrm{min}$. Cell volume was $\sim 26 \mathrm{~cm}^{3}$.

c. Energy not specified; very limited dose rate range.

d. Originally reported in $\mathrm{eV} / \mathrm{s}$ ábsorbed in a total volume of $0.5 \mathrm{~cm}^{3}$.

e. See also 32-0002.

should compete at the dose rates employed and thus could account for the observed dose rate dependence.

At very high dose rates $\left(\geqslant 10^{26} \mathrm{eV} \cdot \mathrm{g}^{-1} \mathrm{~s}^{-1}\right)$, the system is somewhat simpler because radicalproduct reactions are not significant. At $20^{\circ} \mathrm{C}$, yields are unchanged when the dose rate is increased from $2 \times 10^{25} \mathrm{eV} \cdot \mathrm{g}^{-1} \mathrm{~s}^{-1}$ to $2 \times 10^{27} \mathrm{eV} \cdot \mathrm{g}^{-1} \mathrm{~s}^{-1}(1.0-1.7 \mathrm{MeV} \mathrm{e}$; 71-0216). However, at higher temperatures yields of $\mathrm{H}_{2}$ and $\mathrm{N}_{2} \mathrm{H}_{4}$ are lower at the higher dose rate and the effect increases with increasing temperature (see fig. 3.2.3.1). $G\left(\mathrm{~N}_{2}\right)$ remains insensitive to changes in dose rate up to the highest temperature studied, $460^{\circ} \mathrm{C}$. At $20^{\circ}$ reaction (23) probably does not compete effectively with radical-radical reactions at these high dose rates and thus dose rate effects would be expected to be negligible. At higher temperatures, reaction (23) will compete more favorably.

\subsubsection{Temperature}

At dose rates less than about $2 \times 10^{18} \mathrm{eV} \cdot \mathrm{g}^{-1} \mathrm{~s}^{-1} G\left(-\mathrm{NH}_{3}\right)$ increases markedly with increasing temperature and appears to reach a plateau value, of about 10 near $200^{\circ} \mathrm{C}$. Although there is agreement on the plateau value, there is significant variation in data at intermediate temperatures (see fig. 3.2.3.1) which may result at least in part from differences in dose rate and pressure. At all temperatures $\mathrm{H}_{2}$ and $\mathrm{N}_{2}$ are the only products.

A number of interpretations of the effect of temperature have been proposed. Anderson and Winter (67-0546) attributed the increase in $G\left(-\mathrm{NH}_{3}\right)$ with increasing temperature to changes in solvation of $\mathrm{NH}_{4}{ }^{+}$and the influence of solvation upon ion-neutralization. At high temperature $\mathrm{NH}_{4}{ }^{+}$is presumed to be unsolvated and the pertinent reactions are

$$
\begin{gathered}
\mathrm{NH}_{4}^{+}+\mathrm{e}^{-} \rightarrow \mathrm{NH}_{3}^{*}+\mathrm{H} \\
\mathrm{NH}_{3} * \rightarrow \mathrm{NH}_{2}+\mathrm{H} .
\end{gathered}
$$

At low temperatures $\mathrm{NH}_{4}{ }^{+}$is fully solvated and the neutralization reaction is more appropriately written

$$
\mathrm{NH}_{4}{ }^{+}\left(\mathrm{NH}_{3}\right)_{\mathrm{n}}+\mathrm{e}^{-} \rightarrow\left(\mathrm{NH}_{3}\right) *_{n+1}+\mathrm{H} \text {. }
$$

The excess energy associated with the excited $\mathrm{NH}_{3}$ complex is about $80 \mathrm{kcal}$ less than that for $\mathrm{NH}_{3}$ * produced by neutralization of unsolvated $\mathrm{NH}_{4}{ }^{+}$and as a consequence, further dissociation to $\mathrm{NH}_{2}$ and $\mathrm{H}$ is not energetically possible. 


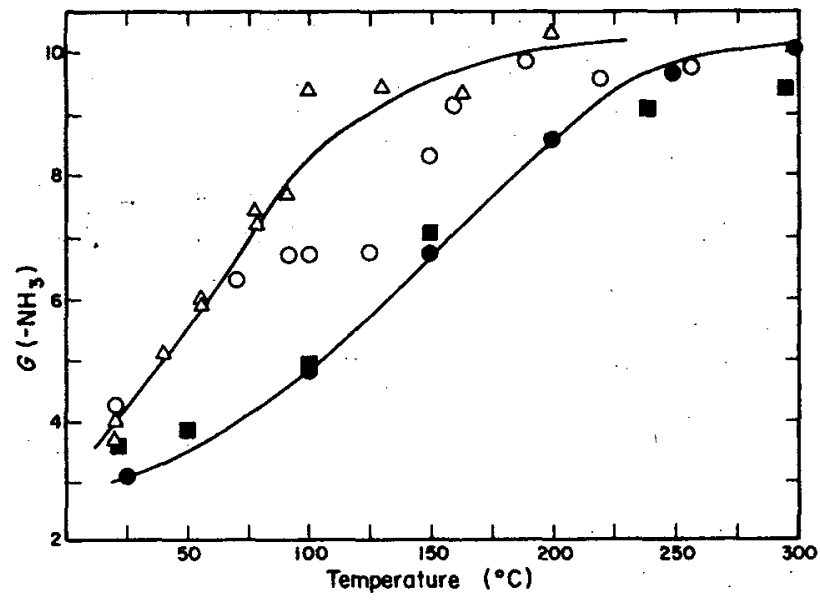

FIGURE 3.2.3.1. Variations of $G\left(-\mathrm{NH}_{3}\right)$ with temperature at dose rates less than $10^{19} \mathrm{eVg}^{-1} \mathrm{~s}^{-1}$. Original data in terms of $\left.G\left(\mathrm{H}_{2}\right) ; G\left(-\mathrm{NH}_{3}\right)=2 / 3 \quad \mathrm{CH}_{2}\right)$. $\bigcirc 67-0546\left(7.0 \times 10^{15} \mathrm{eV} \cdot \mathrm{g}^{-1} \mathrm{~s}^{-1}\right) ; 067-0270(2.0$ $\left.\times 10^{18} \mathrm{eV} \cdot \mathrm{g}^{-1} \mathrm{~s}^{-1}\right) ; \triangle 6 R-0659\left(1.4 \times 10^{16} \mathrm{eV} \cdot \mathrm{g}^{-1} \mathrm{~s}^{-1}\right) ; \square 70-0479\left(3 \times 10^{15} \mathrm{eV} \cdot \mathrm{g}^{-1} \mathrm{~s}^{-1}\right)$.

Solvation of $\mathrm{NH}_{4}{ }^{+}$in gaseous ammonia is known to occur $(68-0032,66-9067,64-9015)$ and modification of ion-neutralization in the manner suggested is not unreasonable. However, considerably higher temperatures than these are required to produce the necessary changes in solvation $(68-0032,66-9067)$. For example at $100^{\circ} \mathrm{C}$ and 1 torr $\mathrm{n}=2$ and neutralization to give more than one $\mathrm{H}$ is still endothermic $(69-0326,66-9067)$. Also, Johnson and Simic (68-0659) have found $G\left(\mathrm{H}_{2}\right)$ from mixtures of ammonia and propane and depression of $G\left(\mathrm{H}_{2}\right)$ from such mixtures by $\mathrm{SF}_{6}$ are independent of temperature, and they conclude that the hydrogen yield from neutralization of $\mathrm{NH}_{4}{ }^{+}$by $\mathrm{e}^{-}$is independent of temperature.

Jones and Sworski (67-0270) have interpreted the effect of temperature in terms of competition between reactions (13), (22), (23) and (24).

$$
\begin{array}{ll}
\text { (13) } & \mathrm{H}+\mathrm{NH}_{2}+\mathrm{M} \rightarrow \mathrm{NH}_{3}+\mathrm{M} \\
\text { (22) } & \mathrm{H}+\mathrm{N}_{2} \mathrm{H}_{4} \rightarrow \mathrm{H}_{2}+\mathrm{N}_{2} \mathrm{H}_{3} \\
\text { (23) } & \mathrm{H}+\mathrm{NH}_{3} \rightarrow \mathrm{H}_{2}+\mathrm{NH}_{2} \\
\text { (24) } \mathrm{H}+\mathrm{H}+\mathrm{M} \rightarrow \mathrm{H}_{2}+\mathrm{M}
\end{array}
$$

They assume that reaction. (23), which has an energy of activation of $10-15 \mathrm{kcal} / \mathrm{mol}(62-0131)$ is unimportant at room temperature but becomes significant at higher temperatures. Johnson and Simic (68-0659) reject this interpretation on the basis that the energy of activation for reaction (23) is too high to account for their observed temperature dependence. They suggest that increase in $\mathrm{G}\left(-\mathrm{NH}_{3}\right)$ with temperature is best explained in terms of competition between reactions (13) and (22). An Arrhenius plot of their data leads to an apparent energy of activation of about 2.1 $\mathrm{kcal} / \mathrm{mol}$. (A similar treatment of the data of Jones and Sworski $(67-0270)$ leads to a value of 1.7.) In terms of their mechanism this apparent energy of activation is to be identified with the differences in activation energies of reactions (22) and (13). Reaction (22) has been reported to have an activation energy of $2.0 \mathrm{kcal} / \mathrm{mol}(62-0131)$ while (13) would be expected to have an activation energy near zero. Thus, the observed temperature dependence agrees well with their mechanism. An important implication of this mechanism is that reaction (23) is unimportant at least up to $200^{\circ} \mathrm{C}$. However available specific rate data indicates that reaction (23) should compete favorably with reaction (22) at temperatures at least as low as $150^{\circ} \mathrm{C}$. For example if the reasonable assumption is made that the concentration of $\mathrm{NH}_{3}$ is at least $10^{3}$ times greater than the steady state concentration of $\mathrm{N}_{2} \mathrm{H}_{4}$, reaction (23) is about four times faster than reaction (22) at $150^{\circ} \mathrm{C}$ (specific rates from $62-0131$; see also table 2.1 ). 
The temperature dependence of $G\left(-\mathrm{NH}_{3}\right)$ at very high dose rates $\left(\sim 10^{27} \mathrm{eV} \cdot \mathrm{g}^{-1} \mathrm{~s}^{-1} ; 69-0272\right.$, 71-0216) differs significantly from that described above (see figure 3.2.3.2). G(- $\left.\mathrm{NH}_{3}\right)$ is constant up to $200^{\circ} \mathrm{C}$ for a dose rate of $2 \times 10^{27} \mathrm{eV}^{-1} \mathrm{~g}^{-1} \mathrm{~s}^{-1}$; above $200^{\circ} \mathrm{C}$ it increases and does not appear to be leveling off at the highest temperature studied $\left(450^{\circ} \mathrm{C}\right)$. At $2 \times 10^{26} \mathrm{eV} \cdot \mathrm{g}^{-1} \mathrm{~s}^{-1}$ the effect is qualitatively similar but $G\left(-\mathrm{NH}_{3}\right)$ is constant only up to about $125^{\circ} \mathrm{C}$. Reaction (22) should be unimportant at the high dose rate employed, and hence interpretation based upon competition between reactions (13) and (22) can be ruled out. At very high dose rates the effect of temperature appears to be the result of the increasing importance of reaction (23) at higher temperatures. Kinetic analysis of the observed temperature dependence for a dose rate of $2 \times 10^{27} \mathrm{eV} \cdot \mathrm{g}^{-1} \mathrm{~s}^{-1}$ leads to $k_{23}=3.6 \times 10^{9} \exp (-10,500 / \mathrm{RT}) \mathrm{dm}^{3} \mathrm{~mol}^{-1} \mathrm{~s}^{-1}$. The energy of activation is in agreement with reported values of $10-15 \mathrm{kcal} / \mathrm{mol}(62-0131,65-0555)$. However, a similar analysis of data for a dose rate of $2 \times 10^{26} \mathrm{eV} \cdot \mathrm{g}^{-1} \mathrm{~s}^{-1}$ leads to $k_{23}=8 \times 10^{7} \exp (-7,200 / \mathrm{RT}) \mathrm{dm}^{3} \mathrm{~mol}^{-1} \mathrm{~s}^{-1}$. Boyd, Willis and Miller (71-0216) attribute this inconsistency in $k_{23}$ to variations with temperature of the various rate constants required in their calculations of $k_{23}$.

Studies with ${ }^{4} \mathrm{He}^{2+}$ radiation lead to results which are at least qualitatively similar. Thus, Jungers (36-0001) reports an increase in $G\left(-\mathrm{NH}_{3}\right)$ by a factor of 1.9 (absolute yields not reported), and Wourtzel (19-0001) reports the following values: $t\left({ }^{\circ} \mathrm{C}\right), G\left(-\mathrm{NH}_{3}\right) ; 18,2.8 ; 108,5.6 ; 220,8.3$; $315,9.0$. The values of Jungers and Wourtzel were originally reported as $M / N$ and have been converted to $G$ assuming $W=30.5 \mathrm{eV}$ per ion pair for ${ }^{4} \mathrm{He}^{2+}$ radiation (53-0008).

Eyre and Smithies (70-0479) have suggested that part of the observed increase in $G\left(-\mathrm{NH}_{3}\right)$ with increasing temperature may be the result of increased thermal decomposition of $\mathrm{N}_{2} \mathrm{H}_{3}$ and/or $\mathrm{N}_{2} \mathrm{H}_{2}$; and they use such an argument to account for the observed discrepancy between $g(\mathrm{H})$ calculated from the limiting values of $G\left(\mathrm{H}_{2}\right)$ at high temperatures and $g(\mathrm{H})$ obtained by scavenger methods (see sec. 2.2.1).

Finally, it should be noted that $\Phi\left(-\mathrm{NH}_{3}\right)$ for photolysis of gaseous ammonia also increases with temperature over this same range $(32-7001,34-7003,44-7000)$, but results are limited and in poor quantitative agreement.

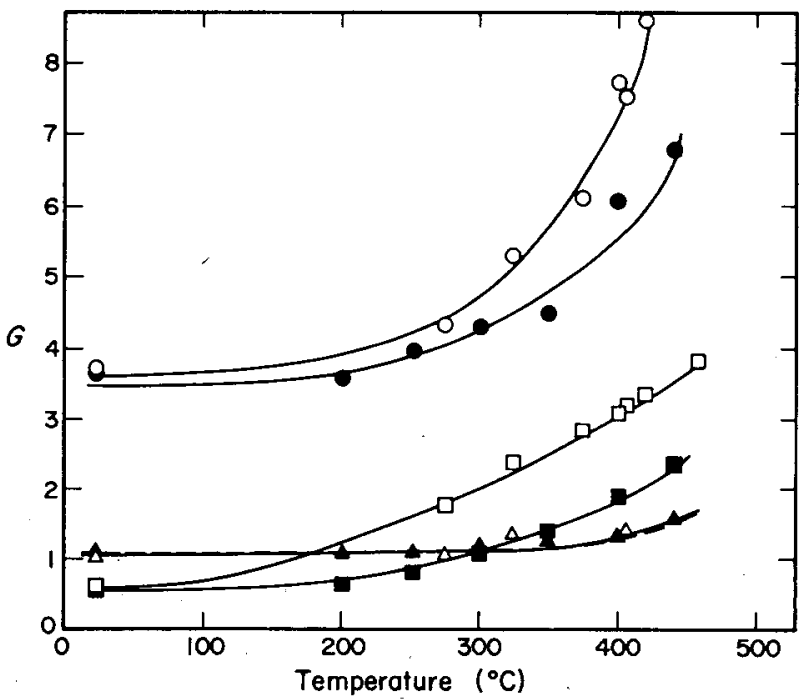

FIGURE 3.2.3.2. Yields of $\mathrm{H}_{2}, \mathrm{~N}_{2} \mathrm{H}_{4}$ and $\mathrm{N}_{2}$ from radiolysis of $\mathrm{NH}_{3}$ vs. temperature (71-0216, 69-0272). $\bigcirc G\left(\mathrm{H}_{2}\right), \square G\left(\mathrm{~N}_{2} \mathrm{H}_{4}\right)$, and $\Delta G\left(\mathrm{~N}_{2}\right)$ at $2 \times 10^{26} \mathrm{eV} \cdot \mathrm{g}^{-1} \mathrm{~s}^{-1} ; G\left(\mathrm{H}_{2}\right), \square G\left(\mathrm{~N}_{2} \mathrm{H}_{4}\right)$, and $\Delta G\left(\mathrm{~N}_{2}\right)$ at $2 \times 10^{27} \mathrm{eV}$. $\mathrm{g}^{-1} \mathbf{s}^{-1}$.

\subsubsection{Pressure}

One atmosphere and below: In a number of the studies summarized in table $3.2 .4 \mathrm{G}\left(-\mathrm{NH}_{3}\right)$ has been reported to increase with decreasing pressure at pressures below one atmosphere.

Jones, Sworski, and Williams (67-0271) using $1 \mathrm{MeV}$ electrons and Carstensen (67-0701) using ${ }^{60} \mathrm{Co}-\gamma$ radiation found $G\left(-\mathrm{NH}_{3}\right)$ independent of pressure down to 400 torr. Below 400 torr 
$\mathrm{T}_{\mathrm{ABI} . \mathrm{E}}$ 3.2.4. Effect of pressures

\begin{tabular}{|c|c|c|c|}
\hline Radiation & Pressure Range & Effect on $G\left(-\mathrm{NH}_{3}\right)$ & Reference \\
\hline 1 $\mathrm{MeV} \mathrm{e}^{-}$ & $47 \rightarrow 800$ torr & $\begin{array}{l}\text { See fig. } 3.2 .4 \text { for results at } 23^{\circ} \mathrm{C} \text {; At } 200^{\circ} \mathrm{C} \text {, } \\
G\left(-\mathrm{NH}_{3}\right) \text { is independent of } P \text {. }\end{array}$ & Jones..67-0271 \\
\hline Fast $e^{-b}$ & $50 \rightarrow 500$ torr $\left(20^{\circ} \mathrm{C}\right)$ & $\begin{array}{l}\text { Decreases with increasing } P \text {; appears to approach } \\
\text { limit at } \sim 500 \text { torr. } G \text { not given. }\end{array}$ & Sorokin.65-0523 \\
\hline${ }^{\infty} \mathrm{Co}-\gamma$ & $200 \rightarrow 650$ torr $\left(23^{\circ} \mathrm{C}\right)$ & See fig. 3.2.4. & Carstensen67-0701 \\
\hline${ }^{60} \mathrm{Co}-\gamma$ & $100 \rightarrow 760$ torr $\left(23^{\circ} \mathrm{C}\right)$ & None. & Buchanan $70-0134$ \\
\hline${ }^{60} \mathrm{Co}-\gamma$ & 400 torr $\rightarrow 3.2$ atm $\left(41^{\circ} \mathrm{C}\right)$ & None: & Johnson. $68-0659$ \\
\hline${ }^{60} \mathrm{Co}-\gamma$ & $100 \rightarrow 700$ torr $\left(20^{\circ} \mathrm{C}\right)$ & None. . . & Eуге. $70-0479$ \\
\hline${ }^{1} \mathrm{H}^{+}$ & $200 \rightarrow 600$ torr $\left(22^{\circ} \mathrm{C}\right)$ & $\begin{array}{l}\text { Decrease linearly with increasing } P \text {, from } 1.93 \\
\text { to } 1.73 .\end{array}$ & Horscroft64-0174 \\
\hline${ }^{4} \mathrm{He}^{2+}$ & $80 \rightarrow 700$ torr $\left(20^{\circ} \mathrm{C}\right)$ & $\begin{array}{l}\text { Decrease with increasing } P ; \text { total decrease } \\
\text { of } 23 \% \%^{\circ}\end{array}$ & Luyckx $34-0003^{d}$ \\
\hline${ }^{60} \mathrm{Co}-\gamma$ & $1 \rightarrow 12$ atm $\left(20^{\circ} \mathrm{C}\right)$ & None. & Nishikawa.68-0051 \\
\hline${ }^{60} \mathrm{Co}-\gamma$ & $1 \rightarrow 60$ atm $\left(120^{\circ} \mathrm{C}\right)$ & $\begin{array}{l}P(\text { atm }), G\left(-\mathrm{NH}_{3}\right) ; 1,10 ; 7.7,15 ; 9,14.8 ; 30 \\
9.0 ; 60,6.6 .\end{array}$ & Sorokin.64-1757 \\
\hline${ }^{60} \mathrm{Co}-\gamma$ & $1 \mathrm{~atm} \rightarrow 0.312 \mathrm{~g} / \mathrm{cm}^{3}\left(137^{\circ} \mathrm{C}\right)$ & $\begin{array}{l}\text { Sharp decrease from } 4.1 \text { to } 1.4 \text { at density near } \\
0.15 \mathrm{~g} / \mathrm{cm}^{3} \text {. }\end{array}$ & Toi...62-0074 \\
\hline
\end{tabular}

a. In all cases incident intensity was constant and therefore variation in pressure is accompanied by a variation in energy absorbed per unit volume per unit time.

b. Energy not specified.

c. Author attributes important but unspecified part of this decrease to changes in absorbed intensity. See $a$ above.

d. See also $57-0018$.

e. See also $69-0026$.

$G\left(-\mathrm{NH}_{3}\right)$ increases from about 2.9 to a maximun of about 4 at 100 torr. Buchanan and Hanrahan (70-0134) failed to observe a similar increase in their study of ${ }^{60} \mathrm{Co}-\gamma$ radiolysis of $\mathrm{NH}_{3}$. They found $G\left(-\mathrm{NH}_{3}\right)$ independent of pressure from one atmosphere to 100 torr, the lowest pressure studied. Eyre and Smithies (70-0479) also found $G\left(-\mathrm{NH}_{3}\right)$ independent of pressure over this same pressure range.

Luyckx (34-0003) observed an increase in $G\left(-\mathrm{NH}_{3}\right)$ of about $23 \%$ for a decrease in pressure from 700 to 80 torr in a study of ${ }^{4} \mathrm{He}^{2+}$ radiolysis of ammonia. He attributed an important, albeit unspecified, part of this decrease to the accompanying variations in intensity. Under conditions of constant incident intensity a decrease in pressure is accompanied by a decrease in the energy absorbed per unit volume per unit time. All of the studies summarized in table 3.2 .4 were carried out under such conditions; however, the decrease in intensity associated with a change in pressure from one atmosphere to about 100 torr should not affect $G\left(-\mathrm{NH}_{3}\right)$ by more than about $10 \%$ (see sec. 3.2.2).

Burtt and Zahlan (57-0018) tried to determine the effect of pressure in the range $700-70$ torr under conditions of nearly constant intensity using ${ }^{4} \mathrm{He}^{2+}$ radiation. They conclude that $G\left(-\mathrm{NH}_{3}\right)$ increases with decreasing pressure but the experimental data are limited and not especially convincing.

Horscroft $(64-0174)$ has reported an essentially linear increase in $G\left(-\mathrm{NH}_{3}\right)$ of about $10 \%$ between 600 and 200 torr in radiolysis with $0.8 \mathrm{MeV}$ protons. At the dose rate employed, intensity effects should be very small (section 3.2.2.) and the $10 \%$ increase in $G\left(-\mathrm{NH}_{3}\right)$ can probably be attributed solely to the decrease in pressure.

Luyckx (34-0003) has pointed out that his results suggest the existence of an inversion intensity." Near this "inversion intensity", $G\left(-\mathrm{NH}_{3}\right)$ is relatively insensitive to changes in pressure. At higher intensities $G\left(-\mathrm{NH}_{3}\right)$ decreases with increasing pressure and at lower intensities it increases with increasing pressure. The inversion intensity arises because $G\left(-\mathrm{NH}_{3}\right)$ is independent of intensity at pressures below about 140 torr but decreases with increasing intensity at higher pressures. This may account for some of the discrepancies that have been observed. 
$G\left(-\mathrm{NH}_{3}\right)$ might be expected to vary with pressure because of the pressure dependence of radical combination reactions. Combination of two $\mathrm{NH}_{2}$ radicals is apparently pseudo-secondorder at pressures in excess of about 0.45 torr (63-9010); however, combination of $\mathrm{NH}_{2}$ with $\mathrm{H}$ and of $\mathrm{H}$ with $\mathrm{H}$ should remain third order up to significantly higher pressures. Jones, Sworski and Williams (67-0271) attribute their observed increase in $G\left(-\mathrm{NH}_{3}\right)$ between 450 and 100 torr to the decreased importance of combination of $\mathrm{NH}_{2}$ with $\mathrm{H}$. A similar explanation has been offered to account for increases in $\Phi\left(-\mathrm{NH}_{3}\right)$ with decreasing pressure in photolysis of ammonia (54-7002, 39-7001, 35-7002); however, the decrease in $\Phi\left(-\mathrm{NH}_{3}\right)$ begins at lower pressure ( 100 torr).

The rapid and irreproducible decrease in $G\left(-\mathrm{NH}_{3}\right)$ at pressures below 100 torr reported by Jones and Sworski (67-0270) and by Carstensen (67-0701) is similar to the effect observed by Wiig (37-7002, 35-7002) in photolysis of ammonia. Wiig attributed this decrease to combination of $\mathrm{NH}_{2}$ with $\mathrm{H}$ at the walls.

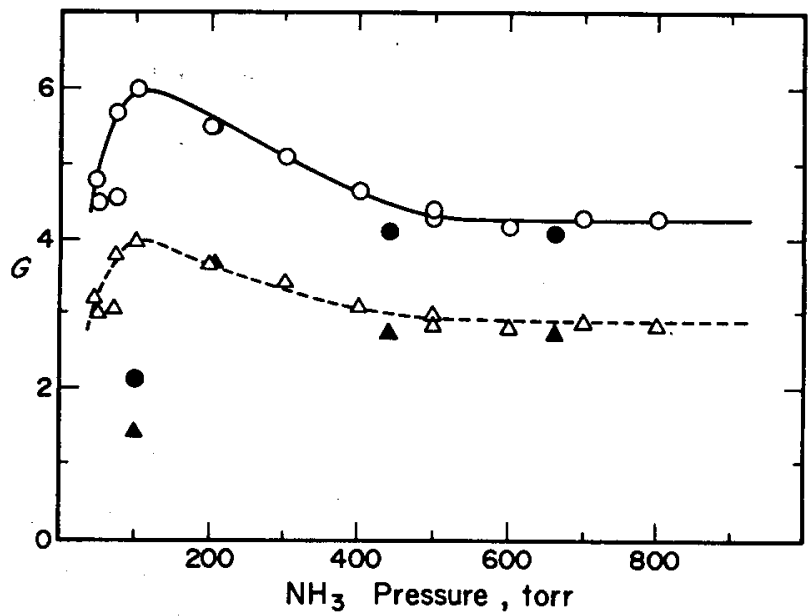

Figure 3.2.4. Variation of $G\left(\mathrm{H}_{2}\right)$ and $G\left(-\mathrm{NH}_{3}\right)$ with pressure $23^{\circ} \mathrm{C} . \triangle G\left(-\mathrm{NH}_{3}\right), \mathrm{O} G\left(\mathrm{H}_{2}\right), 67-0270$ $\left(2 \times 10^{18} \mathrm{eV} \cdot \mathrm{g}^{-1} \mathrm{~s}^{-1}\right) ; \Delta G\left(-\mathrm{NH}_{3}\right), O G\left(\mathrm{H}_{2}\right), 67-0701\left(5 \times 10^{14} \mathrm{eV} \cdot \mathrm{g}^{-1} \mathrm{~s}^{-1}\right)$.

At very high dose rate $\left(2 \times 10^{27} \mathrm{eV} \cdot \mathrm{g}^{-1} \mathrm{~s}^{-1}\right), G\left(-\mathrm{NH}_{3}\right)$ increases rapidly with decreasing pressure below about 700 torr $(69-0272,71-0216)$, but this effect appears to be the result of acceleration of secondary electrons in transient fields created by the pulse.

Pressure above one atmosphere: At higher temperatures, the pressure range can be extended to the point that gas densities approach those of liquid ammonia. Toi, Peterson and Burton (620074) studied ${ }^{60} \mathrm{Co}-\gamma$ radiolysis of gaseous ammonia at $137^{\circ} \mathrm{C}$ over the density range from $5 \mathrm{x}$ $10^{-4} \mathrm{~g} / \mathrm{cm}^{3}$ to $0.312 \mathrm{~g} / \mathrm{cm}^{3}$. They found $G\left(-\mathrm{NH}_{3}\right)$ decreased rather sharply from 4.1 to 1.4 at densities near $0.15 \mathrm{~g} / \mathrm{cm}^{3}$. Further increase in density had little effect upon $G\left(-\mathrm{NH}_{3}\right)$. They interpreted this decrease in terms of the effect of ion-clustering upon ion-neutralization. However, this interpretation seems improbable in light of more recent investigation of ionclustering in ammonia (64-9015, 66-9067, 68-0032). Recent work by Nishikawa, Kuroda, and Matsuura (69-0026) over this same density range is in good agreement with the earlier study of Toi et al. They suggest the decrease in $G\left(-\mathrm{NH}_{3}\right)$ is the result of neutralization of $\mathrm{NH}_{4}^{+}$by $\mathrm{NH}_{2}{ }^{-}$, i.e.,

$$
\mathrm{NH}_{4}^{+}+\mathrm{NH}_{2}^{-} \rightarrow 2 \mathrm{NH}_{3} .
$$

rather than by an electron. They speculate that at high densities $\mathrm{NH}_{2}$ may compete successfully with $\mathrm{NH}_{4}{ }^{+}$for electrons because of unspecified alteration in the electrostatic field of $\mathrm{NH}_{4}^{+}$. 


\subsubsection{Electric Field}

Electric fields have been applied to systems during radiolysis to obtain information about the role of ion-neutralization processes (for a general discussion of this technique see G.G. Meisels, 68-0650, page 364). In the case of ammonia, electric fields less than about $5 \mathrm{~V} \cdot \mathrm{cm}^{-1}$ torr $^{-1}$ do not significantly affect $G\left(-\mathrm{NH}_{3}\right)$.

The earliest investigations $(38-0002,42-0001,55-0010,57-0018)$ were carried out with relatively low-intensity $\left(10^{13}-10^{14} \mathrm{eV} \cdot \mathrm{g}^{-1} \mathrm{~s}^{-1}\right){ }^{4} \mathrm{He}^{2+}$ radiation over a pressure range of 200 to 620 torr at $25^{\circ} \mathrm{C}$. In the first of these $(38-0002)$, a significant decrease $(\sim 30 \%)$ in $G\left(-\mathrm{NH}_{3}\right)$ with increasing field strength was reported at 620 torr, and on the basis of this observed decrease it was concluded that $34 \%$ of the overall reaction was attributable to ion-recombination. However, this decrease was not observed in subsequent studies under similar conditions in the same laboratory using more highly purified ammonia (55-0010, 57-0018).

More recently, Jones and Sworski (67-0270) carried out a study of the effect of applied field upon radiolysis with $1 \mathrm{MeV}$ electrons. At 200 torr and $23^{\circ} \mathrm{C}$ they find $\mathrm{G}\left(-\mathrm{NH}_{3}\right)$ is independent of field strength up to about $5 \mathrm{~V} \cdot \mathrm{cm}^{-1}$ torr ${ }^{-1} ; G\left(-\mathrm{NH}_{3}\right)$ increases with increasing field strength above $5 \mathrm{~V} \cdot \mathrm{cm}^{-1}$ torr ${ }^{-1}$ because of excitation of $\mathrm{NH}_{3}$ by collision with electrons accelerated in the field. These results suggest that the net chemical effect of ion-neutralization is the same whether the neutralization occurs homogeneously or at a surface.

\subsubsection{Flow Rate}

Most studies of gaseous ammonia have been made under static conditions. In such cases, hydrazine is not obtained in measurable yields at dose rates below $\sim 10^{26} \mathrm{eV} \cdot \mathrm{g}^{-1} \mathrm{~s}^{-1}(69-0272,68-$ $0101)$ presumably because of radical-hydrazine reactions. Jones, Sworski and Williams (67-0271) have studied radiolysis of $\mathrm{NH}_{3}$ in this low dose rate range with $1 \mathrm{MeV}$ electrons under both static and flow conditions. Hydrazine is not produced in measurable yields under static conditions but it is an important product in flow systems. Yields of $\mathrm{N}_{2} \mathrm{H}_{4}$ increase with increasing flow rate and decreasing intensity. At constant flow rate and intensity, $G\left(\mathrm{~N}_{2} \mathrm{H}_{4}\right)$ increases markedly with increasing temperature. At a constant beam current of $5 \mu \mathrm{A}$ and constant flow rate of 2.5 $\mathrm{dm}^{3} / \mathrm{min}, G\left(\mathrm{~N}_{2} \mathrm{H}_{4}\right)$ increases from 0.62 to 2.97 as the temperature is increased from $25^{\circ} \mathrm{C}$ to $300^{\circ} \mathrm{C}$. The highest yield observed was $G\left(\mathrm{~N}_{2} \mathrm{H}_{4}\right)=3.95$ for a beam current of $0.05 \mu \mathrm{A}$ and a flow rate of $2.5 \mathrm{dm}^{3} / \mathrm{min}$ at $300^{\circ} \mathrm{C}$.

In flow systems hydrazine is removed from the reaction zone and rapidly diluted so that radical-hydrazine reactions are considerably less important than in static systems. Increasing temperature and decreasing intensity further reduce the probability of such $\mathrm{N}_{2} \mathrm{H}_{4}$-consuming reactions. An increase in temperature is assumed to increase the imnortance of reaction (23) relative to the reaction of $\mathrm{H}$ with $\mathrm{N}_{2} \mathrm{H}_{4}$, and decrease

$$
\text { (23) } \mathrm{H}+\mathrm{NH}_{3} \rightarrow \mathrm{H}_{2}+\mathrm{NH}_{2}
$$

in intensity probably favors production of $\mathrm{N}_{2} \mathrm{H}_{4}$ by reducing the steady-state concentration of $\mathrm{H}$. 


\section{Appendix 1. Selected Properties of Species Involved in Radiolysis of Gaseous Ammonia}

See tables A.1.1 and A.1,2.

TABI.E. A.1.1. Properties of neutral species

\begin{tabular}{|c|c|c|c|c|c|c|}
\hline Species & $\begin{array}{l}\Delta H_{i}^{\circ}(298 \mathrm{~K}) \\
(\mathrm{kcal} / \mathrm{mol})\end{array}$ & $\begin{array}{l}\text { I.P. } \\
(\mathrm{eV})\end{array}$ & $\begin{array}{l}P . A . \\
(\mathrm{eV})\end{array}$ & $\begin{array}{l}E . A \\
(\mathrm{eV})\end{array}$ & $\begin{array}{l}D(298 \mathrm{~K}) \\
(\mathbf{k c a l} / \mathrm{mol})\end{array}$ & Other properties \\
\hline $\mathrm{NH}_{3}$ & -11.02 & 10.2 & $9.2-9.4^{b}$ & c & $D\left(\mathrm{NH}_{2}-\mathrm{H}\right)=104 \pm 2$ & $\begin{array}{l}W=30.5 \pm 0.4\left({ }^{210} \mathrm{Po}^{-\alpha}\right){ }^{\mathrm{b}} \\
26.5 \pm 0.4\left(1 \mathrm{MeV} \mathrm{e}^{-}\right) .^{i} \\
S_{\mathrm{A}}=0.719^{j} . \mathrm{UV} \text { spectrum. } \\
\mathrm{e}^{-} \text {impact spectrum. }\end{array}$ \\
\hline $\mathrm{NH}_{2}$ & 41 & 11.4 & - & $1.21,1.22^{\mathrm{d}}$ & $D(\mathrm{NH}-\mathrm{H})=90 \pm 2$ & $\begin{array}{l}\text { UV spectrum. }{ }^{\text {m }} \text { Fluorescence } \\
\text { spectrum }{ }^{\circ} \text { ESR spectrum. }\end{array}$ \\
\hline NH & 79 & 13.1 & - & - & $D(\mathrm{~N}-\mathrm{H})=85 \pm 2$ & $\begin{array}{l}\text { UV spectrum. }{ }^{D} \text { Fluorescence } \\
\text { spectrum. } .^{q}\end{array}$ \\
\hline $\mathrm{N}_{2} \mathrm{H}_{4}(\mathrm{~g})$ & 22.80 & 8.74 & - & - & $\begin{array}{l}D\left(\mathrm{H}_{2} \mathrm{~N}-\mathrm{NH}_{2}\right)=59 \pm 3 \\
D\left(\mathrm{~N}_{2} \mathrm{H}_{3}-\mathrm{H}\right)=76 \pm 2\end{array}$ & - \\
\hline $\mathrm{N}_{2} \mathrm{H}_{3}$ & $\sim 47^{\circ}$ & 7.88 & - & - & - & - \\
\hline $\mathrm{N}_{2} \mathrm{H}_{2}$ & $49 \pm 5^{\prime}$ & 9.85 & - & $\dot{-}$ & $D(\mathrm{HN}=\mathrm{NH})=109 \pm 5^{\star}$ & - \\
\hline $\mathrm{H}$ & 52.10 & 13.6 & - & - & - & - \\
\hline $\mathrm{H}_{2}$ & 0 & 15.4 & 3.0 & -0.72 & $D(\mathrm{H}-\mathrm{H})=104.2$ & - \\
\hline $\mathrm{N}_{2}$ & 0 & 15.6 & - & $\longrightarrow$ & $D(\mathrm{~N}-\mathrm{N})=225.96$ & - \\
\hline
\end{tabular}

a. Unless otherwise indicated values have been taken from the following sources. Standard heats of formation $\left(\Delta H_{i}^{\circ}\right)$, Wagman.... 68-9060; Ionization potentials (I.P.), Franklin....69-9067; proton affinities $(P . A$.$) and$ electron affinities $(E . A$.$) , Vedeneyev....62-9017; bond dissociation energies (D)$, Darwent 70-9007.

b. See also 55-9002 and 68-7069. Entropy of protonation is $-27.55 \mathrm{eV} / \mathrm{deg}(55-9002)$.

c. Doesn't form a stable negative ion with thermal electrons. At $\sim 3 \mathrm{eV} \mathrm{NH}^{-}$is detected (34-9002). See also 66-0298.

d. Page 73, 62-9019.

e. Calculated from $D\left(\mathrm{~N}_{2} \mathrm{H}_{3}-\mathrm{H}\right)$ and $\Delta H_{1}^{\circ}$ of $\mathrm{H}$ and $\mathrm{N}_{2} \mathrm{H}_{4}$.

f. Calculated by combining mass spectrometric and thermal data (Foner and Hudson 58-9004).

g. Calculated from $\Delta H_{1}^{\circ}$ of $\mathrm{N}_{2} \mathrm{H}_{2}$ and $\mathrm{NH}$.

h. Biber..53-0008.

i. Meisels 64-0177.

j. Stopping power relative to air, Meisels $64-0177$.

k. $105-165 \mathrm{~nm}$ with $0.7 \mathrm{~nm}$ resolution, Okabe and Lenzi67-7484 (includes threshold for various photodissociation processes); 140-220 nm, Watanabe 54-9006; 85-230 nm, Duncan 35-9001.

1. Skerbele and Lassettre 65-9040.

m. Herzberg and Ramsay 52-7001; Ramsey 53-7003. Gordon, Mulac and Nangia 71-0169 (pulsed radiolysis).

n. Okabe and Lenzi $67-7484$.

o. Adrian..62-5011 (in argon at $4.2 \mathrm{~K}$ ); Marx.68-5178; Smith.(70-0335) $\left({ }^{14} \mathrm{NH}_{2},{ }^{14} \mathrm{ND}_{2},{ }^{15} \mathrm{NH}_{2},{ }^{15} \mathrm{ND}_{2}\right.$ ).

p. Meaburn and Gordon 68-0101 (pulsed radiolysis); Husain and Norrish 63-7008; Ramsay 53-7003.

q. Okabe and Lenzi 67-7484; Becker and Welge 63-6002. 
TABI.E A.1.2. Properties of ionic species"

\begin{tabular}{|c|c|c|c|c|}
\hline Ion & $\begin{array}{l}\Delta H_{\mathrm{f}}^{\circ}(298.2 \mathrm{~K}) \\
(\mathrm{kcal} / \mathrm{mol})\end{array}$ & $\begin{array}{l}\text { A.P. } \\
(\mathrm{eV})\end{array}$ & $\begin{array}{l}\text { Relative abundance } \\
\left(2 \times 10^{-7} \text { torr }\right)\end{array}$ & Comments \\
\hline $\mathrm{NH}_{4}{ }^{+}$ & $154(55-9002)$ & - & 0 & $\begin{array}{l}\text { Accounts for } 97 \% \text { of positive ions at } \\
1 \text { torr }(66-0298) \text { because of rapid } \\
\text { ion-molecule reactions. Solvated at } \\
\text { normal temperatures and pressures } \\
(66-9067,68-0032,64-9015,65-0775 \text {, } \\
71-9024) \text {. }\end{array}$ \\
\hline $\mathrm{NH}_{3}{ }^{+}$ & 223 & 10.2 & 100 & $\begin{array}{l}\text { Rapidly converted to } \mathrm{NH}_{4}^{+} \text {at } P \text { near } \\
\text { l torr }(66-0298) \text {. }\end{array}$ \\
\hline $\mathrm{NH}_{2}{ }^{+}$ & 304 & 16.0 & 40.92 & $\begin{array}{l}\text { Rapidly converted to } \mathrm{NH}_{4}^{+} \text {at } P \text { near } \\
\text { l torr }(66-0298) \text {. }\end{array}$ \\
\hline $\mathrm{NH}^{+}$ & 382 & $\begin{array}{l}17.1\left(+\mathrm{H}_{2}\right) \\
21.6(+2 \mathrm{H})\end{array}$ & 4.50 & See table 2.1 for reactions of $\mathrm{NH}^{+}$ \\
\hline
\end{tabular}

a. Unless otherwise indicated values have been taken from the following sources. Standard heats of formation $\left(\Delta H_{\mathrm{i}}^{\circ}\right)$ and appearance potentials $(A . P$.$) , Wagman....68-9060; relative abundances, Melton 66-0298.$ 


\section{Appendix 2. Additives Used in Studies of Ammonia Radiolysis}

Tables A.2.1 and A.2.2 are intended primarily as an index to the additives that have been employed in studies of the radiation chemistry of gaseous ammonia. No attempt has been made to include detailed results; however, a number of these additives have been given rather extensive consideration in section 2. Tables A.2.1 and A.2.2 do not include studies of additives employed exclusively for purposes of synthesis (viz., synthesis of amines).

TABLE A.2.1. Additives: Binary mixtures

\begin{tabular}{|c|c|c|c|c|}
\hline Additive & Concn. range, mol \% & Radiation & Comments & Reference \\
\hline Argon & $0 \rightarrow 80$ & ${ }^{60} \mathrm{Co}-\gamma$ and fast $\mathrm{e}^{-}$ & $\begin{array}{l}\text { Efficient energy transfer from } \\
\text { Ar to } \mathrm{NH}_{3} \text {. }\end{array}$ & Sorokin.65-0523 \\
\hline Benzene & $0 \rightarrow 4.3$ & ${ }^{60} \mathrm{Co}-\gamma$ & $\begin{array}{l}\text { Used to determine } g\left(\mathrm{H}_{2}\right) \text {. } \\
\text { See table } 2.2 .3 \text {. }\end{array}$ & Carstensen67-0701 \\
\hline Benzene & 3.0 & ${ }^{60} \mathrm{Co}-\gamma$ & ditto. & Johnson. 68-0659 \\
\hline Benzene & $0 \rightarrow 7.4$ & ${ }^{60} \mathrm{Co}-\gamma$ & ditto. & Eyre.70-0479 \\
\hline $\begin{array}{l}\text { Carbon } \\
\text { tetrachloride }\end{array}$ & $2 \rightarrow 9$ & ${ }^{60} \mathrm{Co}-\gamma$ & $\begin{array}{l}\text { Used to study ion-neutralization. } \\
\text { See section } 2.1 .1 \text {. }\end{array}$ & Nishikawa.68-0051 ${ }^{b}$ \\
\hline $\begin{array}{l}\text { Carbon } \\
\text { tetrachloride }\end{array}$ & $0 \rightarrow 5$ & ${ }^{60} \mathrm{Co}-\gamma$ & ditto. & Eyre.70-0479 \\
\hline Cyclohexane & $0 \rightarrow 6.5$ & ${ }^{\infty 0} \mathrm{Co}-\gamma$ & $\begin{array}{l}\text { Used to determine } g(\mathrm{H}) \\
\text { See section } 2.2 .1 \text {. }\end{array}$ & Eyre.70-0479 \\
\hline Deuterium & $0 \rightarrow 20$ & $1 \mathrm{MeV} \mathrm{e}^{-}$ & $\begin{array}{l}G(\mathrm{HD}) \text { from } \mathrm{NH}_{3}-\mathrm{D}_{2} \text { used to est- } \\
\text { imate } g(\mathrm{H}) \text {. See section } 2.2 .1 \text {. }\end{array}$ & Jones. $67-0270$ \\
\hline Deuterium & $0 \rightarrow 4.7$ & ${ }^{60} \mathrm{Co}-\gamma$ & $\begin{array}{l}\text { Suggest chain reaction involved } \\
\text { in production of HD. }\end{array}$ & Johnson.68-0659 \\
\hline Ethylene & $0 \rightarrow 7$ & $1 \mathrm{MeV} \mathrm{e}^{-}$ & $\begin{array}{l}\text { Used to determine } g\left(\mathrm{H}_{2}\right) \text {. } \\
\text { See table } 2.2 .3 \text {. }\end{array}$ & Jones. $67-0270$ \\
\hline Ethylene & $2 \rightarrow 4$ & ${ }^{60} \mathrm{Co}-\gamma \cdot$ & ditto. Also used $C_{2} D_{4}$ & Nishikawa.68-0051 \\
\hline Ethylene & $0 \rightarrow 3$ & $250 \mathrm{keV} \mathrm{\textrm {e } ^ { - }}$ & $\begin{array}{l}\text { Pulse radiolysis. Decreases } \\
t_{0.5} \text { for decay of } \mathrm{NH} .\end{array}$ & Meaburn.68-0101 \\
\hline Hydrazine & $\begin{array}{l}0 \rightarrow 1.3 \text { at } 600 \text { torr } \\
0 \rightarrow 4 \text { at } 200 \text { torr }\end{array}$ & $1 \mathrm{MeV} \mathrm{e}^{-}$ & $\begin{array}{l}\text { Used to determine } g(\mathrm{H}) \text {. See } \\
\text { section } 2.2 .1 \text {. }\end{array}$ & Jones. $67-0270$ \\
\hline Hydrazine & $0 \rightarrow 1$ & ${ }^{60} \mathrm{Co}-\gamma$ & ditto. & Carstensen67-0701 \\
\hline Hydrazine & 5.3 and 7.4 & ${ }^{60} \mathrm{Co}-\gamma$ & Very limited study. & Nishikawa..69-0326 \\
\hline Hydrazine & $0 \rightarrow 2.2$ & ${ }^{60} \mathrm{Co}-\gamma$ & Used to determine $g(\mathrm{H})$ & Eyre.70-0479 \\
\hline Hydrogen & $9 \rightarrow 50$ & $0.8 \mathrm{MeV}{ }^{1} \mathrm{H}^{+}$ & $\begin{array}{l}\text { Results are not consistent, but } \\
\text { some indication that } G\left(-\mathrm{NH}_{3}\right) \\
\text { decreases at high concn. of } \mathrm{H}_{2} \text {. }\end{array}$ & Horscroft 64-0174 \\
\hline Hydrogen & $12 \rightarrow 90$ & ${ }^{4} \mathrm{He}^{2+}(\mathbf{R n})$ & $\begin{array}{l}G\left(-\mathrm{NH}_{3}\right) \text { decreases but relative- } \\
\text { ly high concn. of } \mathrm{H}_{2} \text { required. }\end{array}$ & Jungers $32-0002$ \\
\hline Iso-propanol & $0 \rightarrow 4.3$ & ${ }^{60} \mathrm{Co}-\gamma$ & $\begin{array}{l}\text { Used to determine } g(H) \text {. See } \\
\text { section } 2.2 .1 \text {. }\end{array}$ & Eyre.70-0479 \\
\hline Krypton & $\sim 90$ & $2 \mathrm{MeV}^{2} \mathrm{H}^{+}$ & $\mathrm{N}_{2} \mathrm{H}_{4}$ only product studied. & Lampe...63-0098 \\
\hline Methanol & $0 \rightarrow 10$ & ${ }^{60} \mathrm{Co}-\gamma$ & Used to determine $g(H)$ & Carstensen67-0701 \\
\hline Methanol & $0 \rightarrow 8.3$ & ${ }^{\infty} \mathrm{Co}-\gamma$ & ditto. & Eyre.70-0479 \\
\hline Neon & $0 \rightarrow 60$ & $\begin{array}{l}{ }^{60} \mathrm{Co}-\gamma \text { and } \\
\text { fast } \mathrm{e}^{-}\end{array}$ & $\begin{array}{l}\text { Efficient energy transfer from } \\
\text { Ne to } \mathrm{NH}_{3} \text {. }\end{array}$ & Sorokin.65-0523 \\
\hline Neon & $\sim 90$ & $2 \mathrm{MeV}^{2} \mathrm{H}^{+}$ & $\mathrm{N}_{2} \mathrm{H}_{4}$ only product studied. & Lampe...63-0098 \\
\hline Nitrogen & $6 \rightarrow 50$ & $0.8 \mathrm{MeV}^{1} \mathrm{H}^{+}$ & $\begin{array}{l}\text { Energy transfer from } \mathrm{N}_{2} \text { to } \\
\mathrm{NH}_{3} \text { at high } \mathrm{N}_{2} \text { concns. }\end{array}$ & Horscroft $64-0174$ \\
\hline Nitrogen & $17 \rightarrow 99$ & ${ }^{4} \mathrm{He}^{2+}(\mathrm{Rn})$ & $\begin{array}{l}\text { Energy transfer from } \mathrm{N}_{2} \text { to } \\
\mathrm{NH}_{3} \text { at high } \mathrm{N}_{2} \text { conens. }\end{array}$ & Jungers32-0002 \\
\hline Nitrous Oxide & $0 \rightarrow 10$ & ${ }^{60} \mathrm{Co}-\gamma$ & $\begin{array}{l}\text { Used to study ion-neutraliza- } \\
\text { tion. See section 2.1.1. }\end{array}$ & Nishikawa.68-0051 \\
\hline Nitrous Oxide & $0 \rightarrow 100$ & ${ }^{\infty} \mathrm{Co}-\gamma$ & ditto. & Johnson. $68-067,9$ \\
\hline
\end{tabular}


TABLE A.2.1. Additives: Binary mixtures - Continued

\begin{tabular}{|c|c|c|c|c|}
\hline Additive & Concn. range, mol \% & Radiation & Comments & Reference \\
\hline \multirow[t]{2}{*}{ Nitric Oxide } & $0 \rightarrow 13$ & ${ }^{60} \mathrm{Co}-\gamma$ & $\begin{array}{l}\text { Reduced } G\left(\mathrm{H}_{2}\right) \text { to } 0.69 . G\left(\mathrm{~N}_{2}\right)= \\
11.9 \text { and presumably } G\left(\mathrm{~N}_{2}\right)= \\
g(\mathrm{NH})+g\left(\mathrm{NH}_{2}\right)\end{array}$ & Eyre. 70-0479 \\
\hline & $0 \rightarrow 3 \times 10^{-3}$ & $2 \mathrm{MeV} \mathrm{e}^{-}$ & $\begin{array}{l}\text { Pulse radiolysis. Studied } \\
\text { effect of } \mathrm{NO} \text { on decay of } \mathrm{NH}_{2} \\
\text { and } \mathrm{NH} \text {. Calculate specific } \\
\text { rates for } \mathrm{NO}+\mathrm{NH} \text { and } \mathrm{NO}+\mathrm{NH}_{2} \text {. } \\
G\left(\mathrm{H}_{2}\right) \text { and } G\left(\mathrm{~N}_{2}\right) \text { reduced. }\end{array}$ & Carstensen67-0701 \\
\hline Oxygen & $0 \rightarrow 6$ & $250 \mathrm{keV} \mathrm{e}^{-}$ & $\begin{array}{l}\text { Pulse radiolysis, no yield data. } \\
\text { Report reduction in } t_{0.5} \text { for } \\
\text { decay of } \mathrm{NH} \text { in presence of } \mathrm{O}_{2} \text {. }\end{array}$ & Meaburn.68-0101 \\
\hline Phosphine & $0 \rightarrow 100$ & ${ }^{60} \mathrm{Co}-\gamma$ & $\begin{array}{l}\text { Yields consistent with } \\
\mathrm{NH}_{2}+\mathrm{PH}_{3} \rightarrow \mathrm{NH}_{3}+\mathrm{PH}_{2} \\
\mathrm{H}+\mathrm{PH}_{3} \rightarrow \mathrm{H}_{2}+\mathrm{PH}_{2} \\
2 \mathrm{PH}_{2} \rightarrow \mathrm{PH}_{3}+\mathrm{PH} \\
2 \mathrm{PH} \rightarrow \mathrm{P}_{2}+\mathrm{H}_{2}\end{array}$ & Buchanan.70-0653 \\
\hline Propane & $0 \rightarrow 6.6$ & ${ }^{60} \mathrm{Co}-\gamma$ & $\begin{array}{l}\text { Used to estimate } g(\mathrm{H}) \text {. See } \\
\text { section } 2.2 .1 \text { and also table } \\
\text { A.2.2. }\end{array}$ & Johnson.68-0659 \\
\hline Propane & $0 \rightarrow 8.6$ & ${ }^{60} \mathrm{Co}-\gamma$ & ditto. & Nishikawa..69-0326 ${ }^{\mathrm{c}}$ \\
\hline Propane & $0 \rightarrow 20$ & ${ }^{60} \mathrm{Co}-\gamma$ & $\begin{array}{l}\text { ditto. Find } G\left(\mathrm{H}_{2}\right) \text { depends upon } \\
\text { dose. }\end{array}$ & Eyre.70-0479 \\
\hline Propylene & 1.5 & ${ }^{60} \mathrm{Co}-\gamma$ & $\begin{array}{l}\text { Used to determine } g\left(\mathrm{H}_{2}\right) \\
\text { See table } 2.2 .3 \text {. }\end{array}$ & Johnson. 68-0659 \\
\hline Propylene & $0 \rightarrow 3.8$ & ${ }^{50} \mathrm{Co}-\gamma$ & ditto. & Nishikawa..67-0263 \\
\hline Propylene & $0 \rightarrow 5$ & ${ }^{60} \mathrm{Co}-\gamma$ & ditto. & Sorokin.64-1757 \\
\hline Propylene & $0 \rightarrow 7.4$ & ${ }^{6} \mathrm{Co}-\gamma$ & ditto. & Eyre.70-0479 \\
\hline Propylene & $0 \rightarrow 9$ & fast $e^{-1}$ & ditto. & Sorokin.65-0523 \\
\hline Propylene & $0 \rightarrow 8$ & $1.0-1.7 \mathrm{MeV}^{-}$ & $\begin{array}{l}\text { Pulse radiolysis. Very high } \\
\text { intensity. }\end{array}$ & Willis..69-0272 \\
\hline Propylene & $0 \rightarrow 3.3$ & $250 \mathrm{keV} \mathrm{e}^{-}$ & $\begin{array}{l}\text { Pulse radiolysis. Results in } \\
\text { increases in } G\left(\mathrm{~N}_{2} \mathrm{H}_{4}\right) \\
(0.07 \text { to } 0.18)\end{array}$ & Meaburn.68-0101 \\
\hline Propylene & $0 \rightarrow 10$ & $2 \mathrm{MeV} \mathrm{e}^{-}$ & $\begin{array}{l}\text { Pulse radiolysis. Studied } \\
\text { effect of } \mathrm{C}_{3} \mathrm{H}_{6} \text { on decay of } \mathrm{NH}_{2} \text {. }\end{array}$ & Gordon..71-0169 \\
\hline \multirow[t]{2}{*}{ Sulfur hexafluoride } & $0 \rightarrow 1.1$ & ${ }^{60} \mathrm{Co}-\gamma$ & $\begin{array}{l}\text { Very limited study. See also } \\
\text { table A.2.2. }\end{array}$ & Nishikawa.69-0326 \\
\hline & $0 \rightarrow 10$ & $2 \mathrm{MeV} \mathrm{e}^{-}$ & $\begin{array}{l}\text { Pulse radiolysis. Studied } \\
\text { effect of } \mathrm{SF}_{6} \text { on decay of } \mathrm{NH}_{2} \text {. } \\
\text { Used to estimate importance of } \\
\text { ion-neutralization. }\end{array}$ & Gordon..71-0169 \\
\hline Xenon & $0 \rightarrow 56$ & $0.8 \mathrm{MeV}^{1} \mathrm{H}^{+}$ & $\begin{array}{l}\text { Efficient energy transfer from } \\
\text { Xe to } \mathrm{NH}_{3} \text {. }\end{array}$ & Horscroft64-0174 \\
\hline $\begin{array}{l}\text { Xenon } \\
\text { Xenon }\end{array}$ & $\begin{array}{l}0 \rightarrow 80 \\
\sim 24\end{array}$ & $\begin{array}{l}{ }^{\infty} \mathrm{Co}-\gamma \\
\mathrm{X} \text {-rays }(40 \mathrm{kV})\end{array}$ & $\begin{array}{l}\text { ditto. } \\
\text { ditto. }\end{array}$ & $\begin{array}{l}\text { Sorokin. } 65-0523 \\
\text { Guenther. } 37-0001\end{array}$ \\
\hline
\end{tabular}

a. Energy not specified.

b. See also 67-0263.

c. See also $68-0505$ and $69-0326$. 
TABLE A.2.2. Additives: Ternary mixtures

\begin{tabular}{|c|c|c|c|c|}
\hline Additives & Concn, range, mol \% & Radiation & Comments & Reference \\
\hline $\mathrm{H}_{2}$ and $\mathrm{N}_{2}$ & $\begin{array}{l}\mathrm{H}_{2}: 0 \rightarrow 75 \\
\mathrm{~N}_{2}: 0 \rightarrow 25\end{array}$ & ${ }^{4} \mathrm{He}^{2+}(\mathrm{Rn})$ & - & Jungers $32-0002$ \\
\hline $\mathrm{C}_{3} \mathrm{H}_{8}$ and $\mathrm{N}_{2} \mathrm{O}$ & $\begin{array}{l}\mathrm{C}_{3} \mathrm{H}_{8}: 0 \rightarrow 12 \\
\mathrm{~N}_{2} \mathrm{O} ; 1.5 \text { and } 3.0\end{array}$ & ${ }^{60} \mathrm{Co}-\gamma$ & See section 2.2 .2 & Johnson. $68-0659$ \\
\hline $\mathrm{C}_{3} \mathrm{H}_{8}$ and $\mathrm{N}_{2} \mathrm{O}$ & $\begin{array}{l}\mathrm{C}_{3} \mathrm{H}_{8}: 1 \rightarrow 4 \\
\mathrm{~N}_{2} \mathrm{O}: 5\end{array}$ & ${ }^{60} \mathrm{Co}-\gamma$ & See section 2.2 .2 . & Nishikawa..69-0326 \\
\hline $\mathrm{C}_{3} \mathrm{H}_{8}$ and $\mathrm{SF}_{6}$ & $\begin{array}{l}\mathrm{C}_{3} \mathrm{H}_{8}: 1: 5 \\
\mathrm{SF}_{6}: 0.2\end{array}$ & ${ }^{60} \mathrm{Co}-\gamma$ & See section 2.2 .2 . & Johnson.68-0659" \\
\hline $\mathrm{C}_{3} \mathrm{H}_{8}$ and $\mathrm{SF}_{6}$ & $\begin{array}{l}\mathrm{C}_{3} \mathrm{H}_{8}: 3.6 \\
\mathrm{SF}_{6}: 0 \rightarrow 1.6\end{array}$ & ${ }^{\infty} \mathrm{Co}-\gamma$ & See section 2.2 .2 & Nishikawa..69-0326 \\
\hline $\begin{array}{l}\text { iso-propanol + } \\
\mathrm{N}_{2} \mathrm{O}\end{array}$ & $\begin{array}{l}\text { iso-propanol: } 0.5 \% \\
\mathrm{~N}_{2} \mathrm{O}: \mathrm{O} \rightarrow 1.7 \%\end{array}$ & ${ }^{60} \mathrm{Co}-\gamma$ & See section 2.2 .2 & \\
\hline $\begin{array}{l}\text { iso-propanol + } \\
\mathrm{SF}_{6}\end{array}$ & $\begin{array}{l}\text { iso-propanol: } 0.5 \% \\
\mathrm{SF}_{6}: 0 \rightarrow 1.3 \%\end{array}$ & & & Eyre.70-0479 \\
\hline $\begin{array}{l}\text { iso-propanol }+ \\
\mathrm{CCl}_{4}\end{array}$ & $\begin{array}{l}\text { iso-propanol: } 0.5 \% \\
\mathrm{CCl}_{4}: 0 \rightarrow 1 \%\end{array}$ & ${ }^{60} \mathrm{Co}-\gamma$ & See section 2.2.2. & Eyre.70-0479 \\
\hline
\end{tabular}

a. See also $67-0369$.

The author is profoundly indebted to Dr. Alberta Ross of the Radiation Chemistry Data Center, University of Notre Dame for her generous and most valuable assistance in preparation of this data review. The many helpful editorial comments of Dr. Lewis Gevantman of the National Bureau of Standards are also gratefully acknowledged.

\section{References}

19-0001 Chemical actions of radiation. Wourtzel, E., LE RADIUM 11, 289-98 and 332-47 (1919).

32-0002 Decomposition et synthese de l'ammoniac sous l'action des rayons alpha. Jungers, J.C., BULL. SOC. CHIM. BELGES. 41, 377-98 (1932).

32-7001 The photochemical decomposition of ammonia. Wiig, E.O., Kistiakowsky, G.B. J. AM. CHEM. SOC. 54, 1806-20 (1932).

34-0001 The ion yield in the decomposition of ammonia by alpha rays. Essex, H., FitzGerald, D., J. AM. CHEM. SOC. 56, 65-7 (1934).

34-0003 Influence de l'intensité d'irradiation, de la pression, de la vapeur de mercure et de la nature des parois sur la decomposition radiochimique de $\mathrm{l}^{\prime} \mathrm{NH}_{3}$. Luyckx, A. BULL. SOC. CHIM. BELGES. 43(3), 117-59 (1934).

34-0005 The rate of recombination of atomic hydrogen. II. Smallwood, H.M., J. AM. CHEM. SOC. 56, 1542-9 (1934).
34-7002 Die Kinetik der photochemischen Ammoniakzersetzung. (Das Auftreten eines Zwischenproduktes $\mathrm{NH}_{4}$ ). Farkas, L., Harteck, P., Z. PHYSIK. CHEM., B 25(3/4), 257-72 (1934).

34-7003 The photo decomposition of gaseous ammonia. Ogg. R. A., Jr., Leighton, P.A., Bergstrom, F.W., J. AM. CHEM. SOC. 56, 318-23 (1934).

34-9002 Formation of negative ions in gases by electron attachment. Part I. $\mathrm{NH}_{3}, \mathrm{CO}$, $\mathrm{NO}, \mathrm{HCl}$ and $\mathrm{Cl}_{2}$. Bradbury, N.E., J. CHEM. PHYS. 2, 827-34 (1934).

35-0002 The recombination of hydrogen atoms. Steiner, W., TRANS. FARADAY SOC. 31, 623-36 (1935).

35-7002 Photochemical investigations. I. The effect of ammonia pressure on the quantum yield for the decomposition of ammonia. Wiig, E.O., J. AM. CHEM. SOC. $57,1559-62$ (1935).

35-9001 The ultraviolet absorption spectrum of ammonia. Duncan, A.B.F., PHYS. REV. $47,822-7$ (1935). 
36-0001 The radiochemical decomposition of deutero-ammonia. Jungers, J.C., J. PHYS. CHEM. 40, 155-8 (1936).

37-0001 Hat die Lebensdauer von Gasioner einen Einfluss auf ihre chemische Wirksamkeit. Guenther, P., Holzapfel, L., Z. PHYSIK. CHEM., B 38(4), 211-20 (1937).

37-7002 Photochemical investigations. III. The effect of cell size on the quantum yield for the decomposition of ammonia. Wiig, E.O., J. AM. CHEM. SOC. 59, 827-30 (1937).

38-0002 Effect of electric fields on the decomposition of ammonia by alpha-rays. Smith, C., Essex, H., J. CHEM. PHYS. 6, 188-96 (1938).

38-9001 Recombination of hydrogen atoms. III Amdur, I., J. AM. CHEM. SOC. 60, 2347 - 55 (1938).

39-7001 On the photochemical decomposition of ammonia. Shida, S., REV. PHYS. CHEM. JAPAN 13, 12-30 (1939).

42-0001 Effect of strong electric fields on the radiochemical decomposition of gaseous ammonia. McGuinness, M.J., Jr., Essex, H J. AM. CHEM. SOC. 64, 1908-11 (1942).

44-7000 Recherches sur la photolyse de l'ammoniac. Vanpeé, M., BULL. SOC. CHIM. BELGES. 53, 179-220 (1944).

52-7001 Absorption spectrum of free $\mathrm{NH}_{2}$ radicals. Herzberg, G., Ramsay, D.A., J. CHEM. PHYS. 20, 347 (1952).

53-0008 Arbeit pro Ionenpaar von mehratomigen Gasen fuer Po- $\alpha$-Teilchen. Biber, C., Huber, P., Mueller, A., HELV. PHYS. ACTA. 26, 602 (1953).

53-7003 The absorption spectra of free $\mathrm{NH}$ and $\mathrm{NH}_{2}$ radicals produced by the flash photolysis of hydrazine. Ramsay, D.A., J. PHYS. CHEM. 57, 415-7 (1953).

54-7002 The photolysis of ammonia at $1849 \mathrm{~A}$ in a flow system. McDonald, C.C., Kahn, A., Gunning, H.E., J. CHEM. PHYS. 22(5), 908-16 (1954).

54-9005 Oxidation of hydrazine in solution. Cahn, J.W., Powell, R.E., J. AM. CHEM. SOC. 76, 2568-70 (1954).

54-9006 Photoionization and total absorption cross section of gases. I. Ionization potentials of several molecules. Cross sections of $\mathrm{NH}_{3}$ and NO. Watanabe, K., J. CHEM. PHYS. 22(9), 1564-70 (1954).
55-0010 Effect of variations in source intensity on the alpha induced decomposition of ammonia. Burtt, B.P., Baurer, T., J. CHEM. PHYS. 23, 466-70 (1955).

55-7001 Decomposition of ammonia photosensitized by mercury $6\left({ }^{3} \mathrm{P}_{1}\right)$ atoms. McDonald; C.C., Gunning, H.E., J. CHEM. PHYS. 23(3), 532-41 (1955).

55-9002 Thermodynamic properties of the ammonium ion. Altshuller, A.P., J. AM. CHEM. SOC. 77, 3480-1 (1955).

57-0018 Alpha-induced decomposition of ammonia. II. Effects of variations in intensity and pressure. Burtt, B.P., Zahlan, A.B., J. CHEM. PHYS. 26(4), 846-50 (1957).

58-0051 Behavior of some polyatomic gases in nuclear reactors. Dolle, L., Proc. of Second U.N. Internat. Conf. Peaceful Uses Atomic Energy, Geneva 29. 367-74 (1958). (Publ. 1959).

58-9004 Diimide-identification and study by mass spectrometry. Foner, S.N., Hudson, R.L., J. CHEM. PHYS. 28, 719-20 (1958).

59-9003 Reactions of gaseous ions. Ammonium formation in ionized ammonia. Dorfman, L.M., Noble, P.C., J. PHYS. CHEM. 63, 980-2 (1959).

61-0103 Nitrous oxide as a dosimeter for ionizing radiations. Hearne, J.A., Hummel, R.W. RADIATION RES. 15, 254-67 (1961).

61-9008 Avarmenko, L.I., Kolesnitova, R.V., IZV. AKAD. NAUK., S.S.S.R. OTDEL KHIM., NAUK., 1971 (1961).

62-0074 Effect of density in radiolysis of ammonia. Toi, Y., Peterson, D.B., Burton, M., RAD. RES : 17, 399-407 (1962).

62-0131 Reactions of hydrogen atoms with hydrazine, ammonia, and nitrous oxide. Schiavello; M., Volpi, G.G., J. CHEM. PHYS. 37(7), 1510-3 (1962).

62-0132 Vacuum ultraviolet photochemistry. III. Primary processes in the vacuum ultraviolet photolysis of : water and ammonia. McNesby, J.R., Tanaka, I., Okabe, H., J. CHEM. PHYS. 36(3), 605-7 (1962).

62-5011 ESR studies of inorganic free radicals in photolytic systems. Adrian, F.J., Cochran, E.L., Bowers, V.A., ADVAN. CHEM. SER. 36, 50-67 (1962).

62-7002 Blitzlicht-Photolyse des $\mathrm{NH}_{3}$ im Vakuum-Ultraviolett. Bayes, K.D., 
Becker, K.H., Welge, K.H., Z. NATURFORSCH. PT. A $17, \quad 676-80$ (1962):

62-9017 Bond energies ionization potentials and electron affinities. Vedeneyev, V.I., Gurvich, L.V., Kondrat'yev, V.N., Medvedev, N.A., Frankevich, Ye. L., St. Martin's Press, Edward Arnold Publishers, New York, 202 pp., (1966).

62-9019 Experimental determination of the electron affinities of inorganic radicals. Page, F.M., ADVAN. CHEM. SER. 36, 68-75 (1962).

63-0098 Hydrazine formation in the gas-phase radiolysis of ammonia. Lampe, F.W., Weiner, E.R., Johnston, W.H., Koski, W.S.,. INTERN. J. APPL. RADIATION ISOTOPES 14, 231-5 (1963).

63-0149 Blitzlicht-Photolyse des $\mathrm{NH}_{3}$ im Vakuum-UV (II)., Stuhl, F., Welge, K.H. Z. NATURFORSCH. PT. A 18, 900-6 (1963).

63-0150 Ion-molecule reactions in gaseous ammonia. Derwish, G.A.W., Galli, A., Giardini-Guidoni, A., Volpi, G.G., J. CHEM. PHYS. 39(6), 1599-605 (1963).

63-0165 The gamma radiolysis of ammonia and the methylamines in the gas phase. Schiek, R.C., Thesis, Univ. of New Hampshire, 73 pp. (1963).

63-0167 Mass spectral studies of kinetics behind shock waves. II. Thermal decomposition of hydrazine. Diesen, R.W., J. CHEM. PHYS. 39(9), 2121-8 (1963).

63-6002 Fluoreszenz von NH-Radikalen bei der Photodissoziation des $\mathrm{NH}_{3}$ im VakuumUV. Becker, K.H., Welge, K.H., Z. NATURFORSCH. PT. A 18, 600-3 (1963).

63-7008 The explosive oxidation of ammonia and hydrazine studied by kinetic spectroscopy. Husain, D., Norrish, R.G.W., PROC. ROY. SOC. (LONDON). SER. A 273, 145-64 (1963).

63-9010 Reactions of nitrogen-hydrogen radicals. I. $\mathrm{NH}_{2}$ recombination in the decomposition of ammonia. Hanes, M.H., Bair, E.J., J. CHEM. PHYS. 38(3), 672-76 (1963).

63-9014 Kinetics of three-body atom recombination. Kretschmer, C.B., Petersen, H.L., J. CHEM. PHYS. 39(7), 1772-8 (1963).

64-0174 Proton irradiation of ammonia. Horscroft,
R.C., TRANS. FARADAY SOC. $60,323-$ 34 (1964).

64-0177 Gas-phase dosimetry by use of ionization measurements. Meisels, G.G., J. CHEM. PHYS. 41(1), 51-6 (1964).

64-0288 Recombination of hydrogen atoms in the presence of atmospheric gases. Larkin, F.S., Thrush, B.A., DISC. FARADAY SOC. 37, 112-7 (1964).

64-1757 Decomposition of ammonia by $\gamma-$ radiation. Sorokin, Yu.A., Pshezhetskii, S.Ya., RUSS. J. PHYS. CHEM. 38(3), 434-6 (1964). Translated from, ZH. FIZ. KHIM. 38(3), 798-801' (1964).

64-7002 Recombination and disproportionation of $\mathrm{NH}_{2}$ radicals. Salzman, J.D., Bair, E.J., J. CHEM. PHYS. 41, 3654-5 (1964).

64-7003 Die Primaerprozesse der $\mathrm{NH}_{3}$-Photolyse bei 1470 A. Groth, W., Okabe, H., Rommel, H.J., Z. NATURFORSCH. PT. A 19, 507-8 (1964).

64-7008 Vacuum ultraviolet photochemistry. McNesby, J.H., Okabe, H., ADVAN. PHOTOCHEM. 3, 157-240 (1964).

64-9015 Ion clusters in the ammonia glow discharge. Dawson, P.H., Tickner, A.W., J. CHEM. PHYS. 40, 3745-7 (1964).

64-9016 Decomposition of sulphur hexafluoride in flames by reaction with hydrogen atoms. Fenimore, C.P., Jones, G.W., COMBUST. FLAME 8(3), 231-4(1964).

65-0523 Kinetics and sensitisation of the radiolysis of ammonia in the gas phase under the action of fast electrons. Sorokin, Yu.A., Pshezhetskii, S.Ya., RUSS. J. PHYS. CHEM. (ENGLISH TRANSL.). 39(8), 1037-40 (1965). Translated from, ZH. FIZ. KHIM. 39, 1955-9 (1965).

65-0555 The determination of the rate constants for the reactions between hydrogen and oxygen atoms and ammonia molecules. Aganesyan, K.T., Nalbandyan, A.B. DOKL. PHYS. CHEM. PROC. ACAD. SCI. USSR (ENGLISH TRANSL.). 160(1), 18-21 (1965). Translated from, DOKL. ACAD. NAUK SSSR. 160(1), 162-5 (1965).

65-0775 Mass-spectrometric study of ions at near-atmospheric pressure. II. Ammonium ions produced by the alpha radiolysis of ammonia and their solvation in the gas phase by ammonia and water molecules. Hogg, A.M., Kebarle, P., J. CHEM. PHYS. 43(2), 449-56 (1965). 
65-9040 Electron-impact spectra. Skerbele, A., Lassettre, E.N., J. CHEM. PHYS. 42(1), 395-401 (1965).

65-9041 Reactions of hydrogen atoms in the gas phase. Thrush, B.A., PROGR. REACTION KINETICS 3, 65-95 (1965).

65-9044 The gas-phase decomposition of hydrazine and its methyl derivatives. Eberstein, I.J., Glassman, I., Proc. of the Tenth Symposium (International) on Combustion, Combustion Institute, Pittsburgh, Pa., pp. 365-74 (1965).

65-9046 The reaction of hydrogen atoms with nitrous oxide. Dixon-Lewis, G., Sutton, M.M., Williams, A., J. CHEM. SOC. 5724-9 (1965).

65-9048 The chemistry of diimine. Huening, S., Mueller, H.R., Thier, W., ANGEW. CHEM. INT. ED. ENGL. 4(4), 271-82 (1965).

66-0201 Protron transfer and neutralization reactions in irradiated gases at atmospheric pressure and between $-78^{\circ}$ and $25^{\circ}$ C. Lawrence, R.H.Jr., Firestone, R.F., ADVAN. CHEM. SER. 58, 278-90 (1966).

66-0249 Evidence for thermal hydrogen-atom reactions in irradiated gaseous $\mathrm{HCl}$. Davidow, R.S., Lee, R.A., Armstrong, D.A., J. CHEM. PHYS. 45(9), 3364-9 (1966).

66-0298 Study by mass spectrometry of the decomposition of ammonia by ionizing radiation in a wide-range radiolysis source. Melton, C.E., J. CHEM. PHYS. 45(12), 4414-24 (1966).

66-04.34 Nitrous oxide dosimetry. Effects of temperature, pressure, and electric field. Jones, F.T., Sworski, T.J., J. PHYS. CHEM. 70(5), 1546-52 (1966).

66-8024 Computer program for the kinetic treatment, of radiation-induced simultaneous chemical reactions. Schmidt, K.H., ANL-7199, 51 pp. (Apr. 1966).

66-9067 Ion-solvent molecule interactions studied in the gas phase. Heats and entropies of individual steps. $\mathrm{NH}_{4}{ }^{+} \cdot(\mathrm{n}-1) \mathrm{NH}_{3}+\mathrm{NH}_{3}=$ $\mathrm{NH}_{4}{ }^{+} \cdot \mathrm{nNH}_{3}$ Hogg, A.M., Haynes, R.M., Kebarle, P., J. AM. CHEM. SOC. 88(1), 28-31 (1966).

66-9068 Reactions of thermal energy ions. Part 4. Ion molecule reactions in ammonia and hydrazine. Harrison, A.G., Thynne, J.C.J., TRANS, FARADAY SOC. 62, 2804-14 (1966).

67-0027 Surface catalytic effects in nitrous oxide radiation dosimetry. Lampe, F.W., Kevan, L., Weiner, E.R., Johnston, W.H., J. PHYS. CHEM. 71(5), 1528-9 (1967).

67-0093 Primary processes in the formation of hydrogen atoms in the radiolysis of water vapor. Johnson, G.R.A., Simic, M., J. PHYS. CHEM. 71, 1118-23 (1967)..

67-0263 Effect of hydrogen atom and electron scavengers on the gas-phase radiolysis of ammonia. Nishikawa, M., Shinohara, N., Matsuura, N., BULL. CHEM. SOC. JAPAN 40(8), 1993 (1967).

67-0270 Radiation chemistry of gaseous ammonia. Part I. Radical and molecular product yields. Jones, F.T., Sworski, T.J., TRANS. FARADAY SOC. 63, 2411-25 (1967).

67-0271 Radiation chemistry of gaseous ammonia. Part 2. Hydrazine formation. Jones, F.T., Sworski, T.J., Williams, J.M., TRANS. FARADAY SOC. 63, 2426-34 (1967).

67-0369 Effect of hydrogen atom and electron scavengers on the radiolysis of ammonia gas. Johnson, G.R.A., Simic, M. NATURE 216(5114), 479-80 (1967).

67-0546 The effect of temperature and pressure on the vapour phase $\gamma$-radiolysis of some polar molecules. Anderson, A.R., Winter, J.A., The Chemistry of Ionization and Excitation, Johnson, G.R.A. and Scholes, G. (ed.)., Taylor and Francis Ltd, London, pp. 197-209 (1967).

67-0701 The radiation chemistry of gaseous ammonia. Carstensen, J.T., Thesis, Stevens Inst. of Technology, Hoboken, N.J., 148 pp. (1967).

67-7484 Photodissociation of $\mathrm{NH}_{3}$ in the vacuum ultraviolet. Okabe, H., Lenzi, M., J. CHEM. PHYS. 47(12), 5241-6 (1967).

67-9004 Mass-spectrometric and theoretical evidence for $\mathrm{NH}_{4}$ and $\mathrm{H}_{3} \mathrm{O}$. Melton, C. Joy, H.W., J. CHEM. PHYS. 46(11), 4275-83(1970).

67-9079 Reactions of thermal energy ions. VI. Hydrogen-transfer ion-molecule reactions involving polar molecules. Gupta, S.K., Jones, E.G., Harrison, A.G., Myher, J.J., CAN. J. CHEM. 45, 3107-17 (1967). 
67-9108 An evaluation of kinetic rate data for reactions of neutrals of atmospheric interest. Schofield, K., PLANET. SPACE SCI. 15, 643-70 (1967).

67-9109 Ammonia decomposition in glow discharge. Carbaugh, D.C., Munno, F.J., Marchello, J.M., J. CHEM., PHYS. 47(12), 5211-4 (1967).

68-0032 Ion-solvent-molecule interactions in the gas phase. Enthalpies and entropies for the reactions $\mathrm{NH}_{4}{ }^{+}\left(\mathrm{NH}_{3}\right)_{n-1}+\mathrm{NH}_{3}=$ $\mathrm{NH}_{4}{ }^{+}\left(\mathrm{NH}_{3}\right)_{n}$. Searles, S.K., Kebarle, P., J. PHYS. CHEM: 72(2), 742-3 (1968).

68-0051 Gas-phase radiolysis of ammonia, Effect of density and additives. Nishikawa, M., Shinohara, N., RADIATION RES. 33, 194-203 (1968).

68-0101 Pulse radiolysis of ammonia gas - rate of disappearance of the $\mathrm{NH}$ triplet radical. Meáburn; G.M., Gordòn, S., J. PHYS., CHEM. 72(5), 1592-8 (1968).

68-0318 The dosimetry of very high intensity pulsed electron sources used for radiation chemistry. II. Dosimetry for gaseous samples. Willis, C., Miller, O.A., Rothwell, A.E., Boyd, A.W., ADVAN. CHEM. SER. 81, 539-49 (1968).

68-0505 On the yield of hydrogen atoms in the vapor phase radiolysis of ammonia. Nishikawa, M., Kuroda, K., Matsuura, N., BULL. CHEM. SOC. JAPAN 41(5), 1276 (1968).

68-0555 Radiolysis of gaseous ammonia. Kazanjian, A.R., Brown, A.K., RFP 1089, 7pp., 22 Nov. 1968 (Dow Chemical Co., Rocky Flats Div., Golden, Colo.).

68-0650 Organic gases. Meisels, G.G. Fundamental Processes in Radiation Chemistry, Ausloos, P.(ed.)., (Interscience Publishers, New York, 1968) pp.347-411.

68-0659 Primary processes in the radiolysis of gaseous ammonia. Johnson, G.R.A., Simic, M., ADVAN. CHEM., SER. 82, 197-211 (1968).

68-5013 The measurement of the rate of recombination of hydrogen atoms at room temperature by means of e.s.r. spectroscopy. Bennett, J.E., Blackmore, D.R., PROC. ROY SOC. (LONDON). A $305,553-74$ (1968).

68-5178 ESR study of free radicals produced in the gas phase by low energy electrons.
Marx, R., Mauclaire, G., ADVAN. CHEM. SER. 82, 212-21 (1968).

68-7069. Ion-molecule reactions of $\mathrm{NH}_{3}{ }^{+}$by photoionization. Chupka, W.A., Russell, M.E., J. CHEM. PHYS. 48(4), 1527-33 (1968).

68-7168 The photolysis of ammonia at $2062 \mathrm{~A}$ in the presence of propane. Groth, W.E., Schurath, U., Schindler, R.N., J. PHYS. CHEM. 72(11), 3914-20 (1968).

68-7214 Reactions of nitrogen-hydrogen radicals. III. Formation and disappearance of NH radicals in the photolysis of ammonia: Mantei, K.A., Bair, E.J., J. CHEM. PHYS. 49(7), 3248-56 (1968).

68-9060 Selected values of chemical thermodynamic properties. tables for the first thirty-four elements in the standard order of arrangement. Wagman, D.D., Evans, W.H., Parker, V.B., Halow, I., Bailey, S.M., Schumm, R.H., NBS Technical Note 270-3, January, 1968. 264p. (Natl. Bureau of Standards).

69-0026 Effect of additives in the radiolysis of gaseous ammonia at high densities. Nishikawa, M., Kuroda, K., Matsuura, N., BULL. CHEM. SOC. JAPAN 42(1), 11618 (1969).

69-0085 Effect of density and electron scavengers in nitrous oxide radiolysis. Sears, J.T., J. PHYS. CHEM. 73(4), 1143-46 (1969).

69-0272 Primary yields and mechanism in the radiolysis of gaseous ammonia. Willis, C., Boyd, A.W., Miller, O.A., CAN. J. CHEM. 47(16), 3007-16 (1969).

69-0326 The yield of hydrogen atoms in the vapor phase radiolysis of ammonia. Nishikawa, M., Kuroda, K., Matsuura, N., BULL. CHEM. SOC. JAPAN 42(7), 1783-6 (1969).

69-7017 The photolysis of ammonia at $2062 \mathrm{~A}$ in the presence of ethylene. Schurath, U., Tiedemann, P., Schindler, R.N., J. PHYS. CHEM. 73(2), 456-9 (1969).

69-9067 Ionization potentials, appearance potentials, and heats of formation of gaseous positive ions. Franklin, J.L., Dillard, J.G., Rosenstock, H.M., Herron, J.T., Draxl, K., Field, F.H., NSRDS-NBS 26 - June 1969, 285p. (Natl. Bureau of Standards).

70-0134 A comparative study of the gas-phase radiation chemistry of "phosphine and ammonia. Buchanan, J.W., Hanrahan, 
R.J., RADIATION RES. 42(2), 244-54 (1970).

70-0335 Electron spin resonance spectra of ${ }^{15} \mathrm{~N}$ labelled amino radicals. Smith, D.R., Seddon, W.A., CAN. J. CHEM. 48, 193842 (1970).

70-0479 Primary yields in the $\gamma$ radiolysis of ammonia. Eyre, J.A., Smithies, D. TRANS. FARADAY SOC. 66(9), 2199209 (1970).

70-0563 Ionic collision processes in gaseous ammonia. Ryan, K.R., J. CHEM. PHYS. 53(10), 3844-8 (1970).

70-0653 The radiation chemistry of phosphineammonia mixtures in the gas phase. Buchanan, J.W., Hanrahan, R.J. RADIATION RES. 44(2), 296-304 (1970).

70-7065 Ratio of disproportionation to combination of $\mathrm{N}_{2} \mathrm{H}_{3}$ radicals. Stief, L.J., J. CHEM. PHYS. 52(9), 4841-5 (1970).

70-9007 Bond dissociation energies in simple molecules. Darwent, B.deB., NSRD-NBS 31, 1970, 48p. (Natl. Bureau of Standards).

70-9010 Rate constants for gas phase reactions.
Handbook. Kondratiev, V.N., Izd "Nauka", Moscow, 1970, 351p. (RUS).

71-0002 Ion lifetimes in gaseous ammonia. Wilson, D.E., Armstrong, D.A., J. PHYS CHEM. $75,444-5$ (1971).

71-0062 Radiation chemistry of ethanol: A review of the yields, reaction rate parameters, and spectral properties of transients, Freeman, G. R., NSRDS-NBS 48, in press.

71-0169 Pulse radiolysis of ammonia gas. II. Rate of disappearance of the $\mathrm{NH}_{2}\left(\mathrm{X}^{2} \mathrm{~B}_{1}\right)$ radical. Gordon, S., Mulac, W., Nangia, P., J. PHYS. CHEM. 75(14), 2087-93 (1971).

71-0179 Radiation chemistry of nitrous oxide gas: Primary processes, elementary reactions and yields, Johnson, G. R. A., NSRDS-NBS 45, in press.

71-0216 A re-examination of the yields in the high dose rate radiolysis of gaseous ammonia. Boyd, A.W., Willis, C., Miller, O.A. CAN. J. CHEM. 49(13), 2283-9 (1971).

71-9024 Ion-molecule reactions in $\mathrm{NO}-\mathrm{NH}_{3}$ mixtures. Puckett, L.J., Teague, M.W. BRL R 1521, Jan. 1971, 30p. 